\title{
Cabozantinib-induced osteoblast secretome promotes survival and migration of metastatic prostate cancer cells in bone
}

\author{
Kai-Jie Yu ${ }^{1,5,6, *}$, Jeffrey K. Li ${ }^{1, *}$, Yu-Chen Lee ${ }^{1, *}$, Guoyu $\mathbf{Y u}^{1}$, Song-Chang Lin ${ }^{1}$, \\ Tianhong Pan7, Robert L. Satcher7, Mark A. Titus ${ }^{2}$, Li-Yuan Yu-Lee ${ }^{4}$, Wen Hui \\ Weng ${ }^{6}$, Gary E. Gallick ${ }^{2,3}$ and Sue-Hwa Lin ${ }^{1,2,3}$ \\ ${ }^{1}$ Department of Translational Molecular Pathology, The University of Texas M. D. Anderson Cancer Center, Houston, Texas, USA \\ ${ }^{2}$ Department of Genitourinary Medical Oncology, The University of Texas M. D. Anderson Cancer Center, Houston, Texas, USA \\ ${ }^{3}$ The University of Texas Graduate School of Biomedical Sciences at Houston, Houston, Texas, USA \\ ${ }^{4}$ Department of Medicine, Baylor College of Medicine, Houston, Texas, USA \\ ${ }^{5}$ Division of Urology, Department of Surgery, Chang Gung Memorial Hospital at Linkou, Chang Gung University College of \\ Medicine, Taoyuan, Taiwan \\ ${ }^{6}$ Department of Chemical Engineering and Biotechnology and Graduate Institute of Biochemical and Biomedical Engineering, \\ National Taipei University of Technology, Taipei, Taiwan \\ ${ }^{7}$ Department of Orthopedic Oncology, University of Texas MD Anderson Cancer Center, Houston, Texas, USA \\ *Authors have contributed equally to this work \\ Correspondence to: Sue-Hwa Lin, email: slin@mdanderson.org
}

Keywords: cabozantinib, osteoblast, secretome, anchorage-independent growth, migration

Abbreviations: CM: conditioned medium; PCa: prostate cancer; PMOs: primary mouse osteoblasts; real-time RT-PCR: reverse transcription followed with real-time polymerase chain reaction; ELISA: enzyme-linked immunosorbent assay

Received: May 25, $2017 \quad$ Accepted: July 14, $2017 \quad$ Published: August 24, 2017

Copyright: Yu et al. This is an open-access article distributed under the terms of the Creative Commons Attribution License 3.0 (CC BY 3.0), which permits unrestricted use, distribution, and reproduction in any medium, provided the original author and source are credited.

\section{ABSTRACT}

Therapies that target cancer cells may have unexpected effects on the tumor microenvironment that affects therapy outcomes or render therapy resistance. Prostate cancer ( $\mathrm{PCa}$ ) bone metastasis is uniquely associated with osteoblastic bone lesions and treatment with cabozantinib, a VEGFR-2 and MET inhibitor, leads to a reduction in number and/or intensity of lesions on bone scans. However, resistance to cabozantinib therapy inevitably occurs. We examined the effect of cabozantinib on osteoblast differentiation and secretion in the context of therapy resistance. We showed that primary mouse osteoblasts express VEGFR2 and MET and cabozantinib treatment decreased osteoblast proliferation but enhanced their differentiation. A genome-wide analysis of transcriptional responses of osteoblasts to cabozantinib identified a set of genes accounting for inhibition of proliferation and stimulation of differentiation, and a spectrum of secreted proteins induced by cabozantinib, including pappalysin, IGFBP2, WNT 16, and DKK1. We determined that these proteins were upregulated in the conditioned medium of cabozantinib-treated osteoblasts (CBZCM) compared to control CM. Treatment of C4-2B4 or PC3-mm2 PCa cells with CBZCM increased the anchorage-independent growth and migration of these PCa cells compared to cells treated with control CM. These results suggest that the effect of cabozantinib on the tumor microenvironment may increase tumor cell survival and cause therapy resistance. 


\section{INTRODUCTION}

Many targeted therapies aim to modulate specific cancer signaling pathways. While these therapies are intended for targets that are expressed in cancer cells, these targets frequently are also present in stromal cells in the tumor microenvironment. The unintended targeting of the tumor stromal components may have an impact on the therapeutic efficacy or have unexpected therapy outcomes.

Cabozantinib is a tyrosine kinase inhibitor that has a high affinity for VEGFR2 and MET, with IC50 of $0.035 \pm 0.01 \mathrm{nM}$ and $1.3 \pm 1.2 \mathrm{nM}$, respectively [1]. Cabozantinib was used to treat prostate cancer (PCa) bone metastasis in phase II and III clinical trials [2, 3]. Metastatic $\mathrm{PCa}$ cells in bone frequently induces osteoblastic bone lesions [4]. Due to the bone-forming nature of the PCa bone metastasis, bone scan is commonly used in detecting the bone lesions from $\mathrm{PCa}$. One interesting observation was that cabozantinib treatments led to a reduction in the extent or intensity of bone scans in patients with $\mathrm{PCa}$ bone metastasis $[2,3]$. While the results of phase II clinical trials of cabozantinib on PCa bone metastasis were promising, the phase III clinical trial fails to show improvement in patients' survival [3]. However, cabozantinib was shown to improve outcomes of other cancers and has been approved for the treatment of advanced renal cell carcinoma in patients who have received prior anti-angiogenic therapy [5].

Several possible mechanisms of resistance to cabozantinib treatments in $\mathrm{PCa}$ have been reported. Varkaris et al. [6] have reported that large vessels that express VEGFR1 in the tumors are resistant to cabozantinib treatments. Lee et al. [7] demonstrated that PCa-induced bone provides integrin ligands that support tumor cell survival. Because integrin ligands are present in the tumor microenvironment before cabozantinib administration, this constitutes a de novo mechanism of therapy resistance. Subsequent studies in animal model by Dai et al. [8], Nguyen et al. [9], and Varkaris et al. [6] showed that cabozantinib increases osteoblast differentiation in vitro and bone formation in vivo, suggesting cabozantinib has a direct effect on osteoblasts. Whether the effect of cabozantinib on osteoblasts promotes therapy resistance to cabozantinib has not been examined.

In this study, we used gene expression profile analysis to identify cellular pathways that are modulated by cabozantinib. These alterations are a result of MET or VEGFR2 inhibition in osteoblasts. In addition, we found that cabozantinib induces the secretion of a spectrum of proteins from osteoblasts. These secreted proteins could act as paracrine factors to provide therapy resistance, suggesting that the unintended targeting of the tumor stromal components by cabozantinib may have an impact on the therapy outcomes.

\section{RESULTS}

\section{Expression of MET and VEGFR2 in osteoblasts}

To examine whether osteoblasts could be a target of cabozantinib, we examined whether MET and VEGFR2 are expressed in osteoblasts. Primary mouse osteoblasts (PMOs) were isolated from newborn mouse calvaria and cultured to confluence (D0 osteoblasts). To prepare differentiated PMOs, the D0 osteoblasts were further cultured in differentiation medium for 24 days (D24 osteoblasts), which resulted in an increase in the expression of osteocalcin, a marker of osteoblast differentiation, compared to D0 osteoblasts (Figure 1A, left panel). The expression of VEGFR2 and MET in D0 and D24 osteoblasts were examined by real-time RTPCR. The oligonucleotide primers used in this study is shown in Supplementary Table 1. Real-time PCR showed that D0 osteoblasts express a low amount of VEGFR2, as indicated by the VEGFR2/GAPDH ratio (Figure 1A, middle panel). However, the levels of VEGFR2 are increased 8.5-fold in D24 osteoblasts compared to D0 osteoblasts (Figure 1A, middle panel). These observations are consistent with those reported by Deckers et al. [10], which showed that mouse preosteoblast-like cell line KS483 expressed VEGFR2 during mineralization. Realtime RT-PCR showed that MET is also expressed in PMOs, but the levels of MET in D0 and D24 osteoblasts are similar (Figure 1A, right panel). These results indicate that both MET and VEGFR2 are expressed in primary mouse osteoblasts.

\section{Cabozantinib inhibits proliferation but enhances differentiation of osteoblasts}

We examined the effects of cabozantinib on the proliferation of PMOs. As shown in Figure 1B, cabozantinib inhibited the proliferation of calvarial osteoblasts at a concentration of $100 \mathrm{nM}$. To examine the effect of cabozantinib on osteoblast differentiation, confluent osteoblasts were cultured in differentiation medium containing $\beta$-glycerol phosphate and ascorbic acid for $6,18,24$, and 30 days with or without cabozantinib. Cabozantinib treatment led to a significant increase in the alkaline phosphatase activity, a marker of osteoblast differentiation, throughout the entire time course of differentiation (Figure 1C). Cabozantinib also increases the levels of osteocalcin in the conditioned medium up to 27 days as measured by ELISA (Figure 1D), and the mineralization of osteoblasts as measured by alizarin red $\mathrm{S}$ (Figure 1E) and von Kossa staining (Figure 1F). These observations indicate that cabozantinib treatment increases osteoblast differentiation. 


\section{Transcriptional responses of osteoblasts to cabozantinib treatments}

It is likely that cabozantinib enhances osteoblast differentiation through inhibition of VEGFR2 and METmediated signaling pathways, and this inhibition leads to changes in gene expression. To examine the effects of cabozantinib on the gene expression of osteoblasts, gene array profiling of D24 osteoblasts with or without cabozantinib treatment was performed. Genes that were upregulated or downregulated more than 2 fold and have a p-value $<0.05$ were considered for further analysis. The resulting 2944 genes were analyzed for the pathways involved. In silico analysis with Ingenuity Pathway Analysis (IPA) was used to detect biological pathways altered by cabozantinib treatment. As shown in Figure 2A, pathways involving HGF (a MET ligand) signaling, VEGF family ligand receptor interaction, and VEGF signaling pathways were found to be downregulated by cabozantinib, consistent with cabozantinib inhibition of MET and VEGFR2. In addition to these known targets, we also found that eNOS signaling, leukocyte extravasation signaling, AMPK signaling, and growth hormone signaling pathways in osteoblasts are downregulated by cabozantinib (Figure 2A). Pathways that are upregulated by cabozantinib were also observed. These include cardiac hypertrophy signaling, CREB signaling in neurons, $\mathrm{P} 2 \mathrm{Y}$ purinergic receptor signaling, and NGF signaling (Figure 2B).
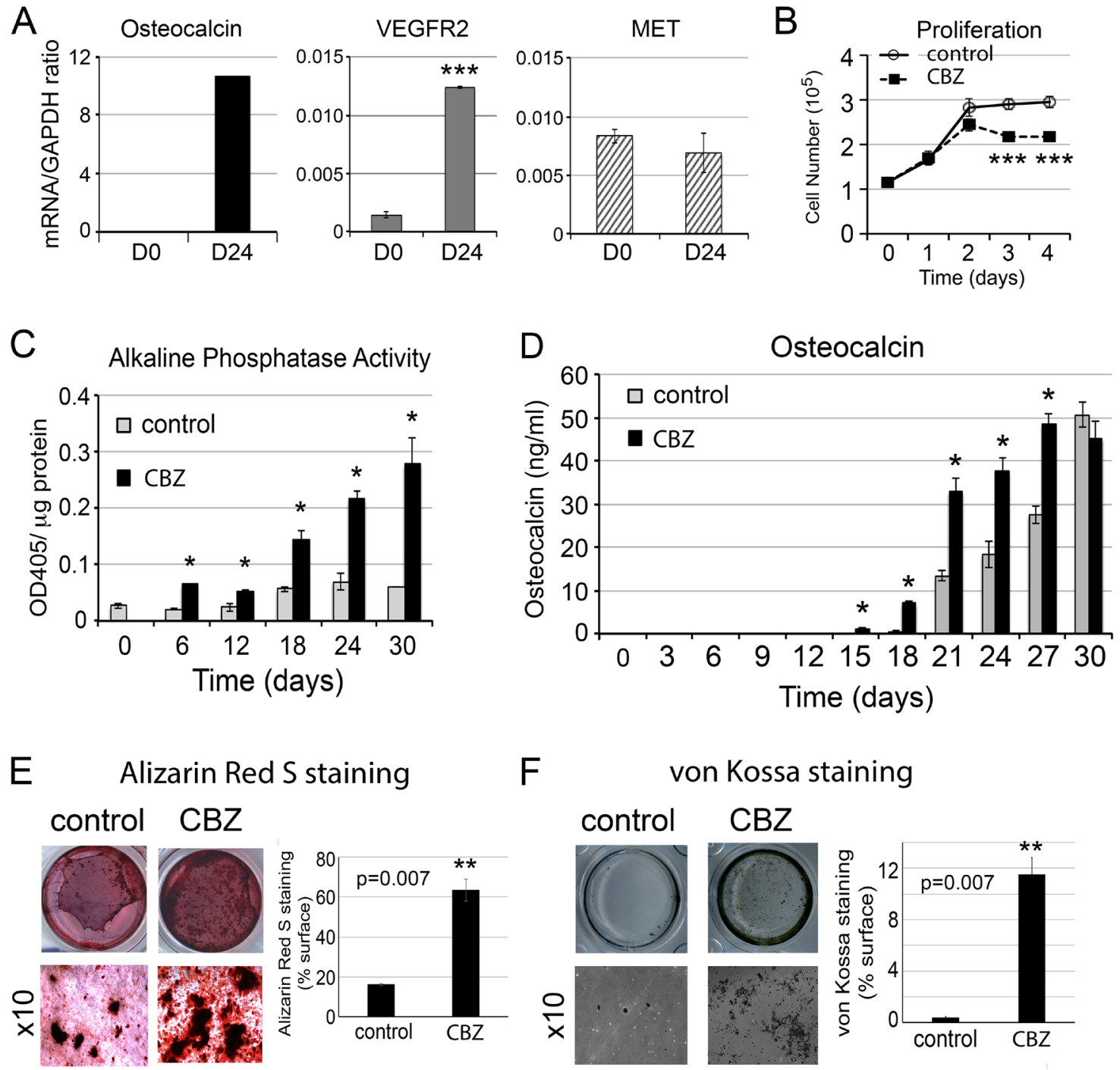

Figure 1: Effect of cabozantinib on osteoblast proliferation and differentiation. (A) Real-time RT-PCR for the expression of osteocalcin, VEGFR2, and MET in the undifferentiated (D0) and differentiated (D24) osteoblasts; (B) Effects of cabozantinib on osteoblast proliferation measured by cell counting; (C) Effects of cabozantinib on osteoblast alkaline phosphatase activity during the time course of osteoblast differentiation; (D) Effects of cabozantinib on osteocalcin protein secretion measured by ELISA; and (E) Effects of cabozantinib on osteoblast mineralization measured by Alizarin Red S staining and (F) von Kossa staining. *, $\mathrm{p}<0.05,{ }^{* *}, \mathrm{p}<0.01, * * *, p<0.001$. 


\section{Genes that enhance osteoblast differentiation}

Next, we used IPA to analyze genes whose changes may be relevant to osteoblast activities. IPA analyses identified 20 genes whose upregulation and 14 genes whose downregulation are associated with "differentiation of osteoblastic-lineage cells" (Figure $2 \mathrm{Ci}$, Table 1, and Table 2). Thus, the analyses predicted that cabozantinib treatment may lead to an increase of osteoblast differentiation (Figure 2Ci). PTPRV, SOX11, ITGA5, TGFB1, NELL1, BMPR2, LTF, WISP1, SFRP2, and PIN1, are among the upregulated genes that are associated with osteoblast differentiation (Figure 2Ci and Figure 2Cii). PTPRV, protein tyrosine phosphatase receptor type $\mathrm{V}$, also known as osteotesticular protein tyrosine phosphatase (OST-PTP) [11], was upregulated
A

Pathways downregulated by CBZ

z-score

$\begin{array}{llllllll}0 & 0.5 & 1 & 1.5 & 2 & 2.5 & 3 & 3.5\end{array}$

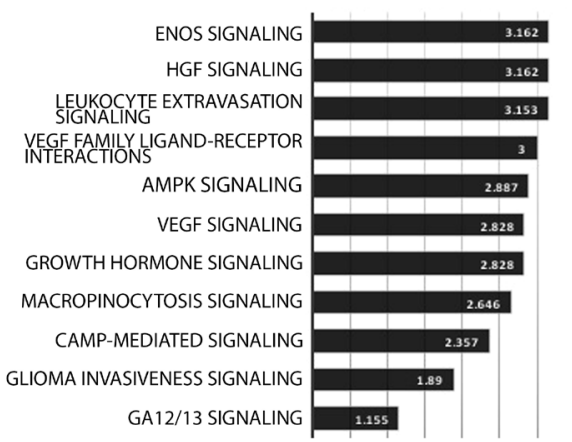

B

Pathways upregulated by $C B Z$

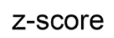

$\begin{array}{lllll}0 & 1 & 2 & 3 & 4\end{array}$

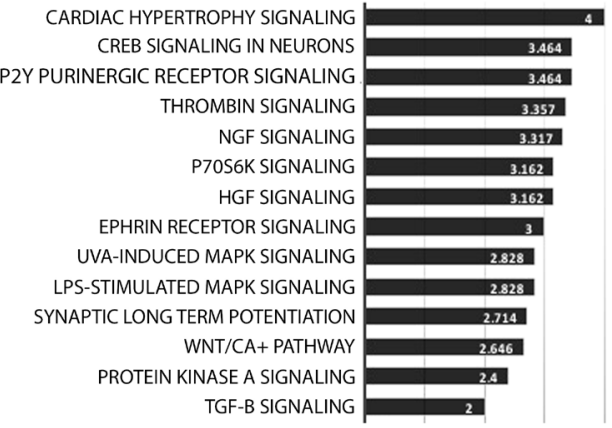

C

(i)

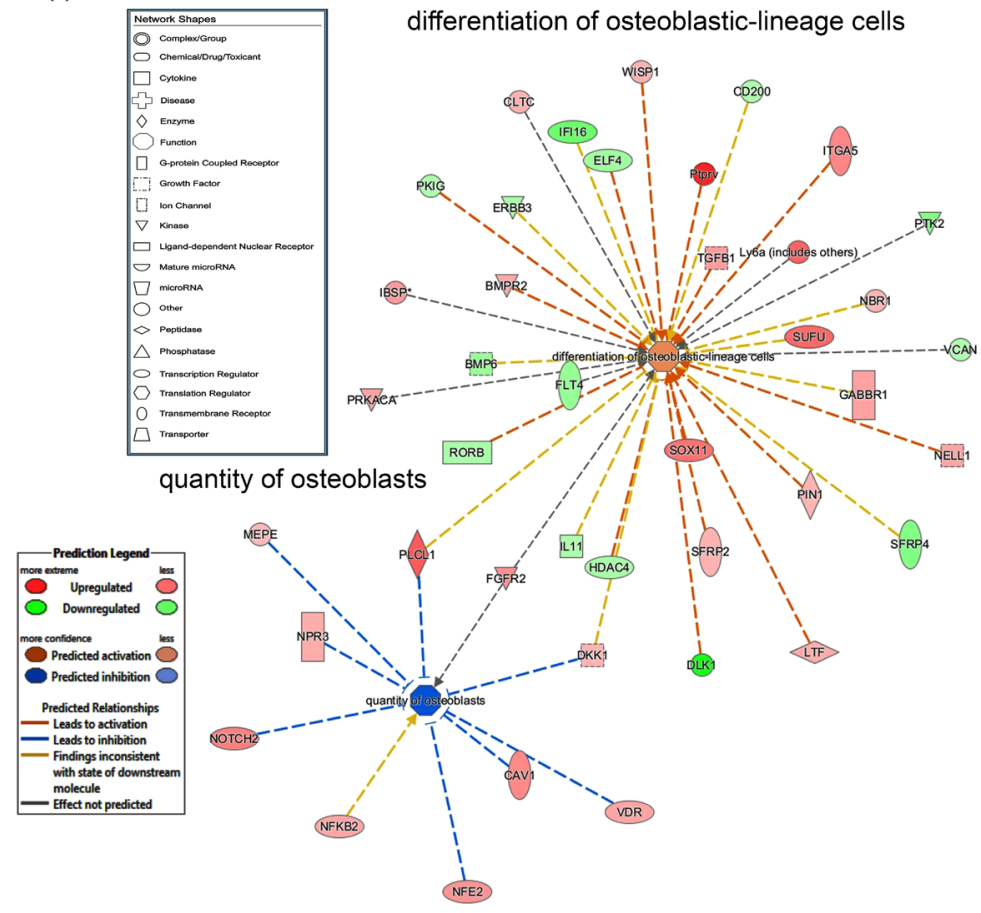

(ii) fold of changes

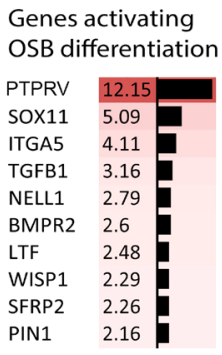

Genes inhibiting OSB differentiation

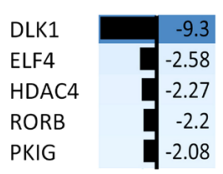

(iii) Genes inhibiting OSB quantity

\begin{tabular}{l|l|l} 
PLCL1 & 6.36 & \\
NOTCH2 & 4.44 & \\
CAV1 & 4.01 & $\square$ \\
NFE2 & 3.47 & $\square$ \\
VDR & 2.87 & $\square$ \\
NPR3 & 2.46 & $\square$ \\
DKK1 & 2.23 & $\square$ \\
MEPE & 2.04 &
\end{tabular}

Figure 2: Pathways affected by cabozantinib treatments using ingenuity pathway analysis (IPA). (A) Pathways that may be affected by genes up-regulated by cabozantinib; (B) Pathways that may be affected by genes down-regulated by cabozantinib; (C) (i) Cabozantinib regulated genes that are involved in "differentiation of osteoblastic-lineage cells" and "inhibition of osteoblast proliferation" based on IPA; (ii) fold of change of up-regulated genes and down-regulated genes related to inhibition of osteoblast differentiation. (iii) fold of change of up-regulated genes related to inhibition of osteoblast quantity. 
Table 1: Cabozantinib upregulated genes that are involved in the "differentiation of osteoblastic-lineage cells"

\begin{tabular}{|c|c|c|c|c|c|}
\hline Symbol & Gene Name & Fold Change & p-value & Location & Family \\
\hline PTPRV & $\begin{array}{l}\text { protein tyrosine } \\
\text { phosphatase, } \\
\text { receptor type, V }\end{array}$ & 12.15 & 0.022 & *Other & $* *$ other \\
\hline SOX11 & SRY-box 11 & 5.09 & 0.001 & Nucleus & $\begin{array}{l}\text { transcription } \\
\text { regulator }\end{array}$ \\
\hline ITGA5 & $\begin{array}{l}\text { integrin subunit } \\
\text { alpha } 5\end{array}$ & 4.11 & 0.005 & Plasma Membrane & $\begin{array}{l}\text { transmembrane } \\
\text { receptor }\end{array}$ \\
\hline TGFB1 & $\begin{array}{l}\text { transforming } \\
\text { growth factor } \\
\text { beta } 1\end{array}$ & 3.16 & 0.001 & $\begin{array}{l}\text { Extracellular } \\
\text { Space }\end{array}$ & growth factor \\
\hline NELL1 & $\begin{array}{l}\text { neural EGFL } \\
\text { like } 1\end{array}$ & 2.79 & $1.00 \mathrm{E}-03$ & $\begin{array}{l}\text { Extracellular } \\
\text { Space }\end{array}$ & growth factor \\
\hline BMPR2 & $\begin{array}{l}\text { bone } \\
\text { morphogenetic } \\
\text { protein receptor } \\
\text { type } 2\end{array}$ & 2.6 & 0.006 & Plasma Membrane & kinase \\
\hline LTF & lactotransferrin & 2.48 & 0.031 & $\begin{array}{l}\text { Extracellular } \\
\text { Space }\end{array}$ & peptidase \\
\hline WISP1 & $\begin{array}{l}\text { WNT1 inducible } \\
\text { signaling pathway } \\
\text { protein } 1\end{array}$ & 2.29 & 0.003 & $\begin{array}{l}\text { Extracellular } \\
\text { Space }\end{array}$ & other \\
\hline SFRP2 & $\begin{array}{l}\text { secreted frizzled- } \\
\text { related protein } 2\end{array}$ & 2.26 & 0.016 & Plasma Membrane & $\begin{array}{l}\text { transmembrane } \\
\text { receptor }\end{array}$ \\
\hline PIN1 & $\begin{array}{l}\text { peptidylprolyl cis/ } \\
\text { trans isomerase, } \\
\text { NIMA- } \\
\text { interacting } 1\end{array}$ & 2.16 & 0.039 & Nucleus & enzyme \\
\hline PLCL1 & $\begin{array}{l}\text { phospholipase } \mathrm{C} \\
\text { like } 1\end{array}$ & 6.36 & 0.0065 & Cytoplasm & enzyme \\
\hline SUFU & $\begin{array}{l}\text { SUFU negative } \\
\text { regulator of } \\
\text { hedgehog } \\
\text { signaling }\end{array}$ & 5.61 & 0.004 & Nucleus & $\begin{array}{l}\text { transcription } \\
\text { regulator }\end{array}$ \\
\hline GABBR1 & $\begin{array}{l}\text { gamma- } \\
\text { aminobutyric acid } \\
\text { type B receptor } \\
\text { subunit } 1\end{array}$ & 2.96 & $4.00 \mathrm{E}-04$ & Plasma Membrane & $\begin{array}{l}\text { G-protein coupled } \\
\text { receptor }\end{array}$ \\
\hline DKK1 & $\begin{array}{l}\text { dickkopf WNT } \\
\text { signaling pathway } \\
\text { inhibitor } 1\end{array}$ & 2.23 & 0.047 & $\begin{array}{l}\text { Extracellular } \\
\text { Space }\end{array}$ & growth factor \\
\hline NBR1 & $\begin{array}{l}\text { neighbor of } \\
\text { BRCA1 gene } 1\end{array}$ & 2.15 & 0.041 & Cytoplasm & other \\
\hline $\begin{array}{l}\text { Ly6a (includes } \\
\text { others) }\end{array}$ & $\begin{array}{l}\text { lymphocyte } \\
\text { antigen } 6 \text { complex, } \\
\text { locus A }\end{array}$ & 5.94 & 0.014 & Plasma Membrane & other \\
\hline
\end{tabular}

(Continued) 


\begin{tabular}{llccll}
\hline Symbol & Gene Name & Fold Change & p-value & Location & Family \\
\hline FGFR2 & $\begin{array}{l}\text { fibroblast growth } \\
\text { factor receptor } 2 \\
\text { InSP }\end{array}$ & 3.71 & 0.026 & Plasma Membrane & kinase \\
& $\begin{array}{l}\text { integrin binding } \\
\text { sialoprotein } \\
\text { protein kinase }\end{array}$ & 3.22 & $1.64 \mathrm{E}-05$ & $\begin{array}{l}\text { Extracellular } \\
\text { Space }\end{array}$ & other \\
PRKACA & $\begin{array}{l}\text { cAMP-activated } \\
\text { catalytic subunit } \\
\text { alpha } \\
\text { clathrin heavy } \\
\text { chain }\end{array}$ & 2.9 & 0.003 & Cytoplasm & kinase \\
CLTC & 2.25 & 0.048 & Plasma Membrane other \\
\hline
\end{tabular}

* The location of the protein has not been defined.

** The function of the protein has not been assigned.

12-fold by cabozantinib treatment in gene array analysis (Figure 2Cii). PTPRV was previously shown to increase osteoblast differentiation [12] and SOX 11 and NELL1 has been shown to play a role in skeletal ossification [13].

To verify the gene array analysis, we tested genes that showed more than a 3 -fold increase, i.e., PTPRV, SOX11, ITGA5 and TGF $\beta 1$, by real-time RT-PCR. For each specific gene examined, three pairs of primers were tested for their specificities and the best oligo pair, which generated high level of predicted product without nonspecific products, was selected for real-time RT-PCR analysis (data not shown). Real-time RT-PCR of the messages prepared from D24 osteoblasts treated with or without cabozantinib showed that the mRNAs of PTPRV and ITGA5 are upregulated by cabozantinib, while SOX11 and TGF $\beta 1$ do not show significant changes in the levels of mRNAs by cabozantinib (Figure 3A).

Among the downregulated genes, DLK1 was downregulated $>9$-fold by cabozantinib treatment (Figure 2Cii). DLK1 was reported to be associated with inhibition of osteoblast differentiation [14]. However, the DLK1 mRNA levels in D24 osteoblasts with or without cabozantinib treatment were too low to be accurately determined (data not shown).

\section{Genes that inhibit osteoblast proliferation}

Next, we analyzed the genes whose changes may be relevant to osteoblast proliferation. IPA analyses identified 10 genes whose upregulation is associated with a decrease of "quantity of osteoblasts" (Figure 2Ci and Table 3). Thus, the analyses predicted that cabozantinib treatment might lead to inhibition of osteoblast quantity (Figure 2Ci). PLCL1, NOTCH2, CAV1, NFE2, VDR, NPR3, DKK1, and MEPE are among the upregulated genes (Table 3 , Figure 2Ciii). Four genes attained the criteria of $>3$-fold change and real-time RT-PCR was performed to determine mRNAs levels in D24 osteoblasts treated with or without cabozantinib. As shown in Figure 3B, the mRNAs of
PLCL1 and CAV1 are upregulated by cabozantinib while those of NOTCH2 and NFE2 are not (Figure 3B). These observations suggest that upregulation of these genes by cabozantinib inhibits osteoblast proliferation.

\section{Cabozantinib induces secretion of factors from osteoblasts}

Cabozantinib treatment may affect factors secreted from osteoblasts. Because of the intimate relationship between osteoblasts and PCa cells in the bone microenvironment, alterations in osteoblast-secreted factors following cabozantinib treatment may have an effect on PCa cells through paracrine effects. Analysis of gene array results revealed 63 secreted factors that are upregulated more than 2-fold following cabozantinib treatment (Table 4). In silico analysis to map the function of these secreted factors identified PAPPA, IGFBP2, DKK1, and TGF $\beta 1$, which have documented effects on "invasion of tumor cells" or "prostate cancer and tumors" (Figure 4A). In addition, WNT16, previously shown to play a role in therapy resistance of $\mathrm{PCa}$ to radiation therapy [15], and LEFTY1, a TGF- $\beta$ family protein required for left-right axis determination [16, 17], are also upregulated by cabozantinib (Table 4). Real-time RT-PCR showed that the mRNAs of PAPPA, IGFBP2, WNT16, LEFTY1, and DKK1 are upregulated by cabozantinib while that of TGF $\beta 1$ is not (Figure 4B).

Western blots were used to further confirm the expression of PAPPA and IGFBP2 in the conditioned medium from osteoblasts treated with or without cabozantinib. Western blot showed that PAPPA, a $\sim 170$ $\mathrm{kDa}$ protein, is expressed at low levels in the PMO conditioned medium throughout the time course of differentiation (Figure 5A). The levels of PAPPA protein in the PMO conditioned medium were significantly increased, about 4-fold, after treating with cabozantinib for 12-24 days (Figure 5B), consistent with the changes seen in message levels (Figure 4B). 
Table 2: Cabozantinib downregulated genes that are involved in the "differentiation of osteoblastic-lineage cells"

\begin{tabular}{|c|c|c|c|c|c|}
\hline Symbol & Gene Name & Fold Change & p-value & Location & Family \\
\hline DLK1 & $\begin{array}{l}\text { delta-like } \\
1 \text { homolog } \\
\text { (Drosophila) }\end{array}$ & -9.30 & 0.010 & $\begin{array}{l}\text { Extracellular } \\
\text { Space }\end{array}$ & $* *$ other \\
\hline ELF4 & $\begin{array}{l}\text { E74 like ETS } \\
\text { transcription } \\
\text { factor } 4\end{array}$ & -2.58 & 0.003 & Nucleus & $\begin{array}{l}\text { transcription } \\
\text { regulator }\end{array}$ \\
\hline HDAC4 & $\begin{array}{l}\text { histone } \\
\text { deacetylase } 4\end{array}$ & -2.27 & 0.022 & Nucleus & $\begin{array}{l}\text { transcription } \\
\text { regulator }\end{array}$ \\
\hline RORB & $\begin{array}{l}\text { RAR related } \\
\text { orphan receptor B }\end{array}$ & -2.20 & 0.016 & Nucleus & $\begin{array}{l}\text { ligand-dependent } \\
\text { nuclear receptor }\end{array}$ \\
\hline PKIG & $\begin{array}{l}\text { protein kinase } \\
\text { (cAMP-dependent, } \\
\text { catalytic) inhibitor } \\
\text { gamma }\end{array}$ & -2.08 & 0.018 & *Other & other \\
\hline IL11 & interleukin 11 & -2.12 & 0.007 & $\begin{array}{l}\text { Extracellular } \\
\text { Space }\end{array}$ & cytokine \\
\hline CD200 & CD200 molecule & -2.23 & 0.002 & Plasma Membrane & other \\
\hline ERBB3 & $\begin{array}{l}\text { erb-b2 receptor } \\
\text { tyrosine kinase } 3\end{array}$ & -2.29 & 0.018 & Plasma Membrane & kinase \\
\hline BMP6 & $\begin{array}{l}\text { bone } \\
\text { morphogenetic } \\
\text { protein } 6\end{array}$ & -2.79 & 0.042 & $\begin{array}{l}\text { Extracellular } \\
\text { Space }\end{array}$ & growth factor \\
\hline SFRP4 & $\begin{array}{l}\text { secreted frizzled } \\
\text { related protein } 4\end{array}$ & -3.56 & 0.004 & Plasma Membrane & $\begin{array}{l}\text { transmembrane } \\
\text { receptor }\end{array}$ \\
\hline IFI16 & $\begin{array}{l}\text { interferon } \\
\text { gamma inducible } \\
\text { protein } 16\end{array}$ & -4.48 & 0.018 & Nucleus & $\begin{array}{l}\text { transcription } \\
\text { regulator }\end{array}$ \\
\hline VCAN & versican & -2.01 & 0.023 & $\begin{array}{l}\text { Extracellular } \\
\text { Space }\end{array}$ & other \\
\hline FLT4 & $\begin{array}{l}\text { fms related } \\
\text { tyrosine kinase } 4\end{array}$ & -2.83 & 0.035 & Plasma Membrane & $\begin{array}{l}\text { transmembrane } \\
\text { receptor }\end{array}$ \\
\hline PTK2 & $\begin{array}{l}\text { protein tyrosine } \\
\text { kinase } 2\end{array}$ & -3.62 & 0.008 & Cytoplasm & kinase \\
\hline
\end{tabular}

* The location of the protein has not been defined.

** The function of the protein has not been assigned.

IGFBP2 is a protein with an apparent molecular weight of around $30 \mathrm{kDa}$. Western blot of the PMO conditioned media showed that IGFBP2 was proteolyzed to 17 and $12 \mathrm{kDa}$ fragments (Figure 5C). Interestingly, previous studies by Gerard et al. [18] showed that IGFBP 2 is proteolyzed by PAPPA in bovine and porcine growing follicles, and they hypothesized that proteolytic cleavage of IGFBP2 contributed to the increase in IGF bioavailability. Quantification of the levels of IGFBP2 by combining the intensities of the intact and proteolyzed fragments showed that the expression of IGFBP2 was increased 8- to 10-fold during PMO differentiation compared to D6 PMO, as undifferentiated D0 PMO did not have detectable levels of IGFBP2 (Figure 5C). Treatment of PMO with cabozantinib during osteoblast differentiation led to a 2- to 3-fold increase of IGFBP-2 (Figure 5D).

ELISAs were used to confirm the expression of WNT16 and DKK1 in the conditioned medium from osteoblasts treated with or without cabozantinib. As shown in Figure 6A, the amount of WNT16 protein in the PMO conditioned medium was significantly increased, about 
2- to 3-fold, after 18-24 days of cabozantinib treatment (Figure 6A). Similarly, the amount of DKK1 protein in the PMO conditioned medium was also significantly increased at 18 or 24 days of cabozantinib treatment (Figure 6B).

\section{Effects of cabozantinib on the expression of RANKL and OPG}

RANKL and OPG are two factors secreted by osteoblasts that play a critical role in the regulation of osteoclast activity. Pantano et al. reported that cabozantinib treatment increased OPG and down-regulated RANKL expression at both message and protein levels in human primary osteoblasts [19]. Stern and Alvares [20] reported that cabozantinib decreases RANKL expression in MC3T3-E1 cells. Thus, it is of interest to examine whether cabozantinib treatment affects RANKL or OPG expression in D24 osteoblasts. In the gene array analysis, we found that the expression of RANKL and OPG in the cabozantinib-treated osteoblasts was 0.99 -fold and 1.07-fold, respectively, compared to control, indicating that cabozantinib may not have an effect on RANKL or OPG expression in differentiated PMOs. Real time RTPCR for the expression of RANKL in undifferentiated (D0) and differentiated (D24) osteoblasts showed that the mRNAs of RANKL was too low to be determined (data not shown). RANKL protein in PMO CMs with or without cabozantinib treatments was also undetectable by ELISA (data not shown). Similarly, ELISA for OPG showed that cabozantinib treatment did not affect OPG protein levels during osteoblast differentiation (Figure 6C). These observations are consistent with the gene array analysis. Together, these results suggest that cabozantinib treatment may not have significant effects on RANKL or OPG expression in mouse PMOs.

\section{Conditioned medium from cabozantinib-treated osteoblasts increases anchorage-independent growth and migration of PCa cells}

Cabozantinib-induced secreted factors from osteoblasts may affect the survival of the tumor cells during cabozantinib treatments. Among the cabozantinibinduced secreted factors, PAPPA was previously shown to be a stroma-secreted factor that can activate $\mathrm{NF} \kappa \mathrm{B}$ signaling in hepatocellular carcinoma (HCC) cells, and advanced stage $\mathrm{HCC}$ has higher expression levels of PAPPA [21]. Increased IGFBP2 was shown to stimulate the proliferation of androgen-independent PCa cells [22, 23] and its expression was shown to be associated with progression of PCa to androgen-independent state [24-26]. WNT16 was previously shown to play a role in therapy resistance [15]. Together, the cabozantinib-induced factors may promote tumor cell survival in a paracrine manner. Thus, we examined the effects of conditioned media from cabozantinib-treated (CBZ-CM) versus untreated (CM) D24 osteoblasts on the survival of PCa cells. At D24, the osteoblasts were fully mineralized (Figure 1). Equal volumes of CBZ-CM and CM were used in the studies. Treatment of C4-2B4 or PC3-mm2 PCa cells with CBZ-

\section{A. Genes increase OSB differentiation}
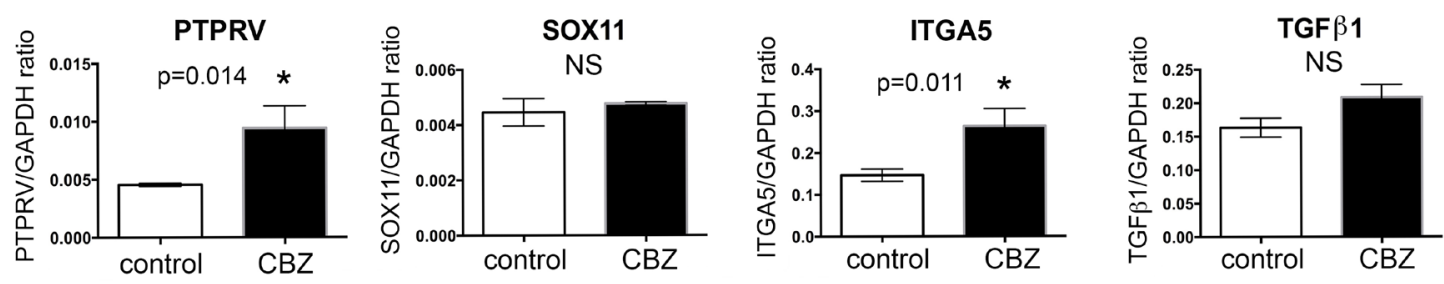

B. Genes decrease OSB quantity
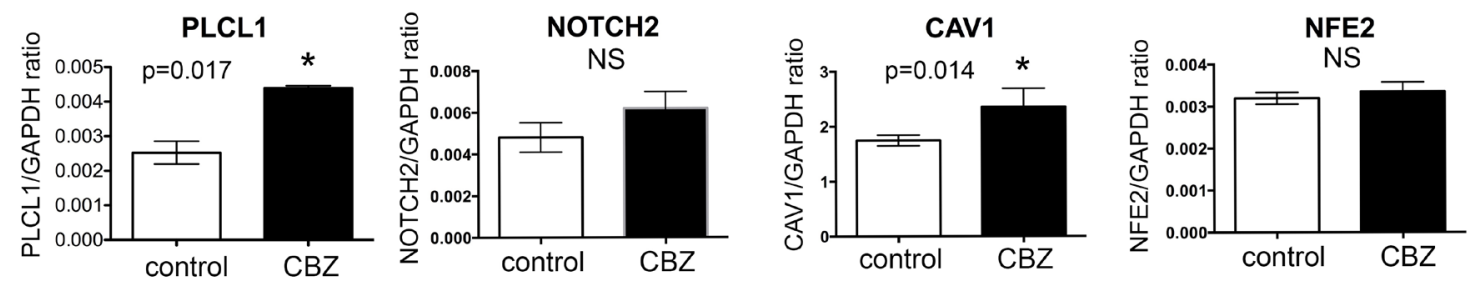

Figure 3: Real-time RT-PCR for mRNA levels of cabozantinib regulated genes involved in "differentiation of osteoblastic-lineage cells" and "inhibition of osteoblast proliferation". (A) Real-time RT-PCR for the mRNAs of genes involved in increase of osteoblast differentiation; (B) Real-time RT-PCR for the mRNAs of genes involved in the inhibition of osteoblast proliferation. *, $\mathrm{p}<0.05$. 
Table 3: Cabozantinib regulated genes that are involved in "quantity of osteoblasts"

\begin{tabular}{|c|c|c|c|c|c|}
\hline Symbol & Gene name & Fold Change & p-value & Location & Family \\
\hline MEPE & $\begin{array}{l}\text { matrix extracellular } \\
\text { phosphoglycoprotein }\end{array}$ & 2.04 & 0.003 & $\begin{array}{l}\text { Extracellular } \\
\text { Space }\end{array}$ & $* *$ other \\
\hline PLCL1 & $\begin{array}{l}\text { phospholipase C } \\
\text { like } 1\end{array}$ & 6.36 & 0.006 & Cytoplasm & enzyme \\
\hline VDR & $\begin{array}{l}\text { vitamin } \mathrm{D}(1,25- \\
\text { dihydroxyvitamin } \\
\text { D3) receptor }\end{array}$ & 2.87 & 0.007 & Nucleus & $\begin{array}{l}\text { transcription } \\
\text { regulator }\end{array}$ \\
\hline NPR3 & $\begin{array}{l}\text { natriuretic peptide } \\
\text { receptor } 3\end{array}$ & 2.46 & 0.014 & Plasma Membrane & $\begin{array}{l}\text { G-protein coupled } \\
\text { receptor }\end{array}$ \\
\hline NFE2 & $\begin{array}{l}\text { nuclear factor, } \\
\text { erythroid } 2\end{array}$ & 3.47 & 0.015 & Nucleus & $\begin{array}{l}\text { transcription } \\
\text { regulator }\end{array}$ \\
\hline CAV1 & caveolin 1 & 4.01 & 0.030 & Plasma Membrane & $\begin{array}{l}\text { transmembrane } \\
\text { receptor }\end{array}$ \\
\hline NOTCH2 & notch 2 & 4.44 & 0.037 & Plasma Membrane & $\begin{array}{l}\text { transcription } \\
\text { regulator }\end{array}$ \\
\hline DKK1 & $\begin{array}{l}\text { dickkopf WNT } \\
\text { signaling pathway } \\
\text { inhibitor } 1\end{array}$ & 2.23 & 0.047 & $\begin{array}{l}\text { Extracellular } \\
\text { Space }\end{array}$ & growth factor \\
\hline NFKB2 & $\begin{array}{l}\text { nuclear factor kappa } \\
\text { B subunit } 2\end{array}$ & 2.74 & 0.043 & Nucleus & $\begin{array}{l}\text { transcription } \\
\text { regulator }\end{array}$ \\
\hline FGFR2 & $\begin{array}{l}\text { fibroblast growth } \\
\text { factor receptor } 2\end{array}$ & 3.71 & 0.026 & Plasma Membrane & kinase \\
\hline
\end{tabular}

** The function of the protein has not been assigned.

$\mathrm{CM}$ increased the anchorage-independent growth of C42B4 and PC3-mm2 cells compared to those treated with $\mathrm{CM}$ (Figure 7A), while treatment of C4-2B4 or PC3-mm2 cells with $100 \mathrm{nM}$ cabozantinib alone did not have a significant effect (Supplementary Figure 1). These results suggest that cabozantinib-induced factors from osteoblasts promote tumor cell survival.

To examine whether cabozantinib-induced secreted factors can activate signaling pathways that affect cell migration, we treated PCa cells with CBZ-CM in a Transwell migration assay. C4-2B4 cells migrated at a very low speed in Transwell migration assay (Figure 7B). Treatment of C4-2B4 cells with CBZ-CM significantly increased the migration of $\mathrm{C} 4-2 \mathrm{~B} 4$ cells compared to the control CM-treated cells (Figure 7B). Similar results were observed with PC3-mm2 cells, however, to a lesser extent, likely due to the highly migratory characteristics of PC3$\mathrm{mm} 2$ cells. Treatment of C4-2B4 or PC3-mm2 cells with $100 \mathrm{nM}$ cabozantinib alone did not have a significant effect on cell migration (Supplementary Figure 1). Together, these results suggest that cabozantinib-induced secreted factors have effects on PCa cells and may contribute to the therapy resistance to cabozantinib.

\section{DISCUSSION}

Our studies address an important issue on the impact of targeted therapy on the tumor microenvironment. We found that cabozantinib treatment leads osteoblasts to undergo differentiation and induces a spectrum of secreted proteins from osteoblasts. Some of these secreted proteins increase PCa cell survival and migration. Because PCa bone metastasis is frequently associated with osteoblastic bone lesions, the effects of cabozantinib on the tumor microenvironment may render therapy resistance as frequently observed in the treatment of patients with $\mathrm{PCa}$ bone metastasis.

Our studies suggest that stromal response to cabozantinib therapy may influence the therapy outcomes. Cabozantinib has high affinity for VEGFR2, which is mainly expressed in endothelial cells. In addition to endothelial cells, osteoblasts are prominently present in bone lesions from metastatic PCa. While endothelial cells show pronounced apoptotic response, osteoblasts respond to cabozantinib with enhanced differentiation. In addition, cabozantinib treatment leads osteoblasts to secrete factors that have effects on PCa cell survival. It is possible that 
Table 4: Cabozantinib upregulated genes that encode secreted factors

\begin{tabular}{|c|c|c|c|c|}
\hline Symbol & Gene Name & Fold Change & p-value & Family \\
\hline NELL1 & neural EGFL like 1 & 2.794 & $9.25 \mathrm{E}-04$ & growth factor \\
\hline TGFB1 & $\begin{array}{l}\text { transforming growth } \\
\text { factor beta } 1\end{array}$ & 3.164 & $1.11 \mathrm{E}-03$ & growth factor \\
\hline NTF4 & neurotrophin 4 & 2.059 & $2.75 \mathrm{E}-02$ & growth factor \\
\hline LEFTY1 & $\begin{array}{l}\text { left-right determination } \\
\text { factor } 1\end{array}$ & 3.53 & $4.22 \mathrm{E}-02$ & growth factor \\
\hline DKK1 & $\begin{array}{l}\text { dickkopf WNT } \\
\text { signaling pathway } \\
\text { inhibitor } 1\end{array}$ & 2.229 & $4.71 \mathrm{E}-02$ & growth factor \\
\hline IFNG & interferon, gamma & 4.285 & 4.44E-03 & cytokine \\
\hline $\mathrm{Ccl} 27 \mathrm{a}$ & $\begin{array}{l}\text { chemokine (C-C } \\
\text { motif) ligand 27A }\end{array}$ & 3.589 & $1.31 \mathrm{E}-02$ & cytokine \\
\hline IBSP & $\begin{array}{l}\text { integrin binding } \\
\text { sialoprotein }\end{array}$ & 3.218 & $1.64 \mathrm{E}-05$ & $* *$ other \\
\hline FAM3A & $\begin{array}{l}\text { family with sequence } \\
\text { similarity } 3 \text { member A }\end{array}$ & 2.882 & $6.53 \mathrm{E}-04$ & other \\
\hline WISP1 & $\begin{array}{l}\text { WNT1 inducible } \\
\text { signaling pathway } \\
\text { protein } 1\end{array}$ & 2.285 & $2.88 \mathrm{E}-03$ & other \\
\hline FAM132B & $\begin{array}{l}\text { family with sequence } \\
\text { similarity } 132 \\
\text { member B }\end{array}$ & 3.75 & $2.93 \mathrm{E}-03$ & other \\
\hline WFDC1 & $\begin{array}{l}\text { WAP four-disulfide } \\
\text { core domain } 1\end{array}$ & 2.395 & $2.99 \mathrm{E}-03$ & other \\
\hline MEPE & $\begin{array}{l}\text { matrix extracellular } \\
\text { phosphoglycoprotein }\end{array}$ & 2.035 & $3.23 \mathrm{E}-03$ & other \\
\hline CFC1/CFC1B & $\begin{array}{l}\text { cripto, FRL-1, cryptic } \\
\text { family } 1\end{array}$ & 6.786 & $4.16 \mathrm{E}-03$ & other \\
\hline AIM1L & $\begin{array}{l}\text { absent in melanoma } \\
\text { 1-like }\end{array}$ & 2.13 & 4.82E-03 & other \\
\hline RASAL2 & $\begin{array}{l}\text { RAS protein activator } \\
\text { like } 2\end{array}$ & 2.119 & 4.96E-03 & other \\
\hline VMO1 & $\begin{array}{l}\text { vitelline membrane } \\
\text { outer layer } 1 \text { homolog } \\
\text { (chicken) }\end{array}$ & 3.936 & $6.43 \mathrm{E}-03$ & other \\
\hline FBLN1 & fibulin 1 & 2.316 & $7.85 \mathrm{E}-03$ & other \\
\hline ITIH4 & $\begin{array}{l}\text { inter-alpha-trypsin } \\
\text { inhibitor heavy chain } \\
\text { family member } 4\end{array}$ & 2.663 & $8.95 \mathrm{E}-03$ & other \\
\hline Hamp/Hamp2 & $\begin{array}{l}\text { hepcidin antimicrobial } \\
\text { peptide }\end{array}$ & 5.98 & $1.18 \mathrm{E}-02$ & other \\
\hline SMTN & smoothelin & 3.985 & $1.29 \mathrm{E}-02$ & other \\
\hline
\end{tabular}

(Continued) 


\begin{tabular}{|c|c|c|c|c|}
\hline Symbol & Gene Name & Fold Change & p-value & Family \\
\hline BPIFB2 & $\begin{array}{l}\text { BPI fold containing } \\
\text { family B member } 2\end{array}$ & 2.534 & $1.62 \mathrm{E}-02$ & other \\
\hline IGFBP2 & $\begin{array}{l}\text { insulin like growth } \\
\text { factor binding } \\
\text { protein } 2\end{array}$ & 5.033 & $1.91 \mathrm{E}-02$ & other \\
\hline PCOLCE2 & $\begin{array}{l}\text { procollagen } \\
\text { C-endopeptidase } \\
\text { enhancer } 2\end{array}$ & 2.148 & $1.98 \mathrm{E}-02$ & other \\
\hline Fena & ficolin A & 2.125 & $2.05 \mathrm{E}-02$ & other \\
\hline MFAP4 & $\begin{array}{l}\text { microfibrillar } \\
\text { associated protein } 4\end{array}$ & 2.188 & $2.06 \mathrm{E}-02$ & other \\
\hline OLFML3 & olfactomedin like 3 & 3.071 & $2.36 \mathrm{E}-02$ & other \\
\hline KLHL5 & $\begin{array}{l}\text { kelch like family } \\
\text { member } 5\end{array}$ & 3.402 & $2.49 \mathrm{E}-02$ & other \\
\hline CRB2 & $\begin{array}{l}\text { crumbs family } \\
\text { member } 2\end{array}$ & 2.055 & $2.57 \mathrm{E}-02$ & other \\
\hline IFT22 & $\begin{array}{l}\text { intraflagellar } \\
\text { transport } 22\end{array}$ & 2.547 & $2.73 \mathrm{E}-02$ & other \\
\hline VSTM2A & $\begin{array}{l}\text { V-set and } \\
\text { transmembrane } \\
\text { domain containing 2A }\end{array}$ & 2.168 & $2.84 \mathrm{E}-02$ & other \\
\hline IL34 & interleukin 34 & 2.859 & $2.95 \mathrm{E}-02$ & other \\
\hline IFT172 & $\begin{array}{l}\text { intraflagellar transport } \\
172\end{array}$ & 5.1 & $2.99 \mathrm{E}-02$ & other \\
\hline WNT16 & $\begin{array}{l}\text { wingless-type MMTV } \\
\text { integration site family } \\
\text { member } 16\end{array}$ & 3.806 & $3.14 \mathrm{E}-02$ & other \\
\hline ADAMTSL1 & ADAMTS like 1 & 4.286 & $3.24 \mathrm{E}-02$ & other \\
\hline SPOCK2 & $\begin{array}{l}\text { sparc/osteonectin, } \\
\text { cwcv and kazal-like } \\
\text { domains proteoglycan } \\
\text { (testican) } 2\end{array}$ & 3.193 & $3.39 \mathrm{E}-02$ & other \\
\hline APCS & $\begin{array}{l}\text { amyloid P component, } \\
\text { serum }\end{array}$ & 3.698 & $3.47 \mathrm{E}-02$ & other \\
\hline SLIT3 & slit guidance ligand 3 & 2.855 & $3.55 \mathrm{E}-02$ & other \\
\hline COL11A2 & $\begin{array}{l}\text { collagen, type XI, } \\
\text { alpha } 2\end{array}$ & 4.198 & $3.68 \mathrm{E}-02$ & other \\
\hline PYY & peptide YY & 3.351 & 4.03E-02 & other \\
\hline WFIKKN2 & $\begin{array}{l}\text { WAP, follistatin/kazal, } \\
\text { immunoglobulin, } \\
\text { kunitz and netrin } \\
\text { domain containing } 2\end{array}$ & 2.424 & 4.27E-02 & other \\
\hline KDM6B & $\begin{array}{l}\text { lysine }(\mathrm{K}) \text {-specific } \\
\text { demethylase } 6 \mathrm{~B}\end{array}$ & 2.073 & 4.30E-02 & other \\
\hline
\end{tabular}

(Continued) 


\begin{tabular}{|c|c|c|c|c|}
\hline Symbol & Gene Name & Fold Change & p-value & Family \\
\hline SCUBE2 & $\begin{array}{l}\text { signal peptide, CUB } \\
\text { domain, EGF-like } 2\end{array}$ & 2.188 & 4.32E-02 & other \\
\hline SERPINE1 & $\begin{array}{l}\text { serpin peptidase } \\
\text { inhibitor }\end{array}$ & 2.171 & $4.61 \mathrm{E}-02$ & other \\
\hline COL22A1 & $\begin{array}{l}\text { collagen, type XXII, } \\
\text { alpha } 1\end{array}$ & 2.628 & 4.93E-02 & other \\
\hline LIPI & lipase, member I & 9.486 & $4.79 \mathrm{E}-04$ & enzyme \\
\hline GFOD2 & $\begin{array}{l}\text { glucose-fructose } \\
\text { oxidoreductase domain } \\
\text { containing } 2\end{array}$ & 2.93 & $6.91 \mathrm{E}-04$ & enzyme \\
\hline FUCA2 & $\begin{array}{l}\text { fucosidase, alpha-L- } 2 \text {, } \\
\text { plasma }\end{array}$ & 2.088 & $3.22 \mathrm{E}-02$ & enzyme \\
\hline LOXL1 & lysyl oxidase like 1 & 2.721 & $4.61 \mathrm{E}-02$ & enzyme \\
\hline PAPPA2 & pappalysin 2 & 12.557 & $4.50 \mathrm{E}-04$ & peptidase \\
\hline MMP8 & $\begin{array}{l}\text { matrix } \\
\text { metallopeptidase } 8\end{array}$ & 3.24 & $5.39 \mathrm{E}-04$ & peptidase \\
\hline PAPPA & $\begin{array}{l}\text { pregnancy-associated } \\
\text { plasma protein } \mathrm{A}, \\
\text { pappalysin } 1\end{array}$ & 2.062 & $1.81 \mathrm{E}-03$ & peptidase \\
\hline СРХМ2 & $\begin{array}{l}\text { carboxypeptidase } \\
\text { X (M14 family), } \\
\text { member } 2\end{array}$ & 2.846 & $6.45 \mathrm{E}-03$ & peptidase \\
\hline CPB1 & carboxypeptidase B1 & 2.991 & $1.32 \mathrm{E}-02$ & peptidase \\
\hline CPA3 & carboxypeptidase A3 & 3.977 & $1.47 \mathrm{E}-02$ & peptidase \\
\hline CPB2 & carboxypeptidase B2 & 2.243 & $2.09 \mathrm{E}-02$ & peptidase \\
\hline CPA4 & carboxypeptidase A4 & 3.1 & $2.36 \mathrm{E}-02$ & peptidase \\
\hline ADAMTS8 & $\begin{array}{l}\text { ADAM } \\
\text { metallopeptidase with } \\
\text { thrombospondin type } 1 \\
\text { motif } 8\end{array}$ & 2.221 & $2.59 \mathrm{E}-02$ & peptidase \\
\hline $\operatorname{Prss} 32$ & protease, serine 32 & 4.528 & $2.69 \mathrm{E}-02$ & peptidase \\
\hline LTF & lactotransferrin & 2.479 & $3.14 \mathrm{E}-02$ & peptidase \\
\hline PCSK5 & $\begin{array}{l}\text { proprotein convertase } \\
\text { subtilisin/kexin type } 5\end{array}$ & 2.491 & $4.84 \mathrm{E}-02$ & peptidase \\
\hline BPGM & $\begin{array}{l}\text { bisphosphoglycerate } \\
\text { mutase }\end{array}$ & 2.414 & $3.26 \mathrm{E}-02$ & phosphatase \\
\hline $\mathrm{A} 2 \mathrm{M}$ & alpha-2-macroglobulin & 2.54 & $3.52 \mathrm{E}-02$ & transporter \\
\hline
\end{tabular}

** The function of the protein has not been assigned.

cabozantinib's effect on osteoblasts contributes to the lack of survival improvement in phase III clinical trial [3]. Because cabozantinib has been approved for the treatment of advanced renal cell carcinoma in patients who have received prior anti-angiogenic therapy, further studies on the effects of cabozantinib on tumor-associated stroma are warranted.

In osteoblasts, MET likely plays a role in supporting osteoblast proliferation. Grano et al. [27] showed that HGF, the ligand for MET, stimulates MET receptor kinase 
activity and MET autophosphorylation in osteoblasts. They also showed that osteoblasts respond to HGF by entering the cell cycle, as indicated by stimulation of DNA synthesis [27]. Consistently, we found that cabozantinib treatment leads to inhibition of osteoblast proliferation. Our transcriptome analysis of cabozantinibtreated osteoblasts unveils proliferation related genes whose expression is modulated by cabozantinib, providing a molecular basis for the inhibition of osteoblast proliferation. The changes in the expression of these genes are likely due to kinase inhibition, which lead to transcriptional reprogramming of osteoblasts.
Other tyrosine kinase inhibitors have also demonstrated effects on osteoblasts. We have previously shown that inhibition of Src/Abl family kinase activity by dasatinib inhibited osteoblast proliferation and increased osteoblast differentiation [28]. Imantinib mesylate that inhibits several tyrosine kinases, including BCR-ABL, PDGFR alpha and beta, and the C-KIT receptor, has also been shown to inhibit osteoblast proliferation and stimulate osteoblast differentiation in vitro [29]. Thus, inhibition of osteoblast proliferation coupled with enhancement of osteoblast differentiation seems to be a common effect of inhibitors that target tyrosine kinases.
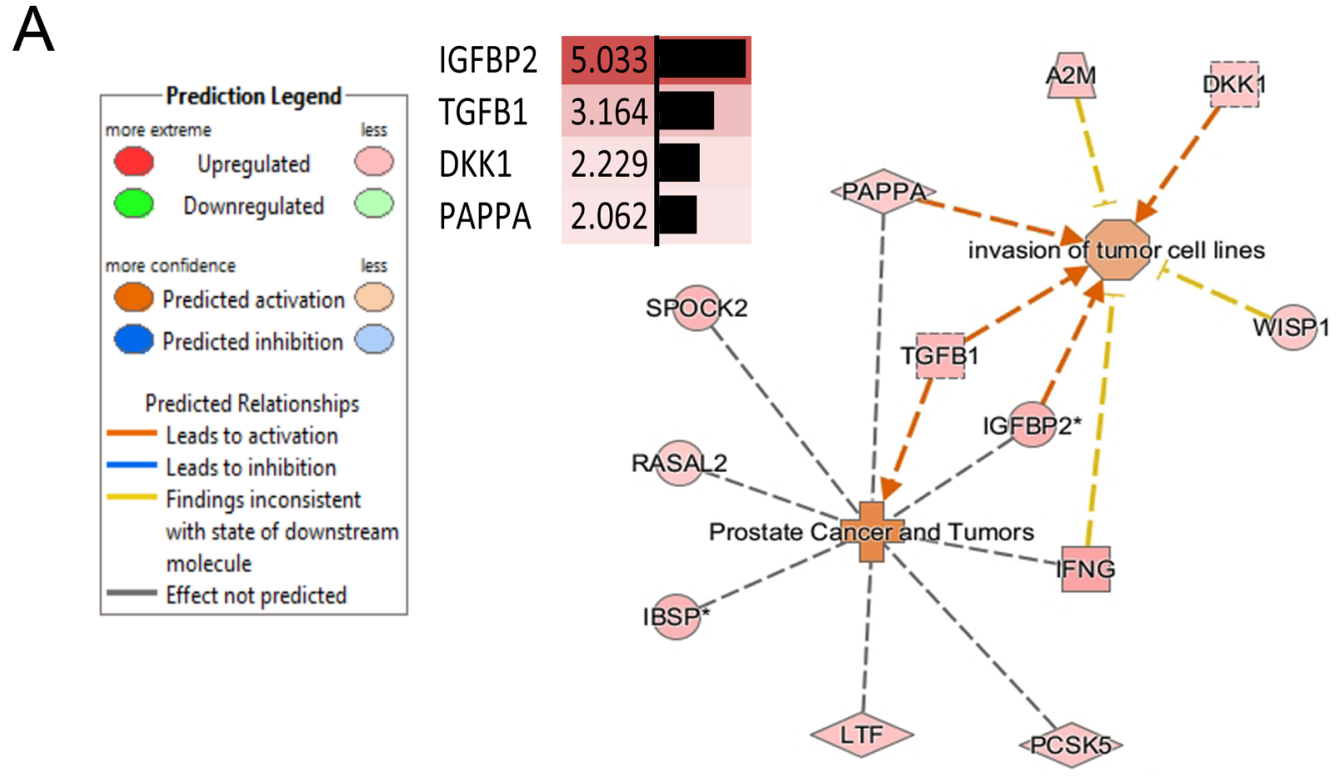

B
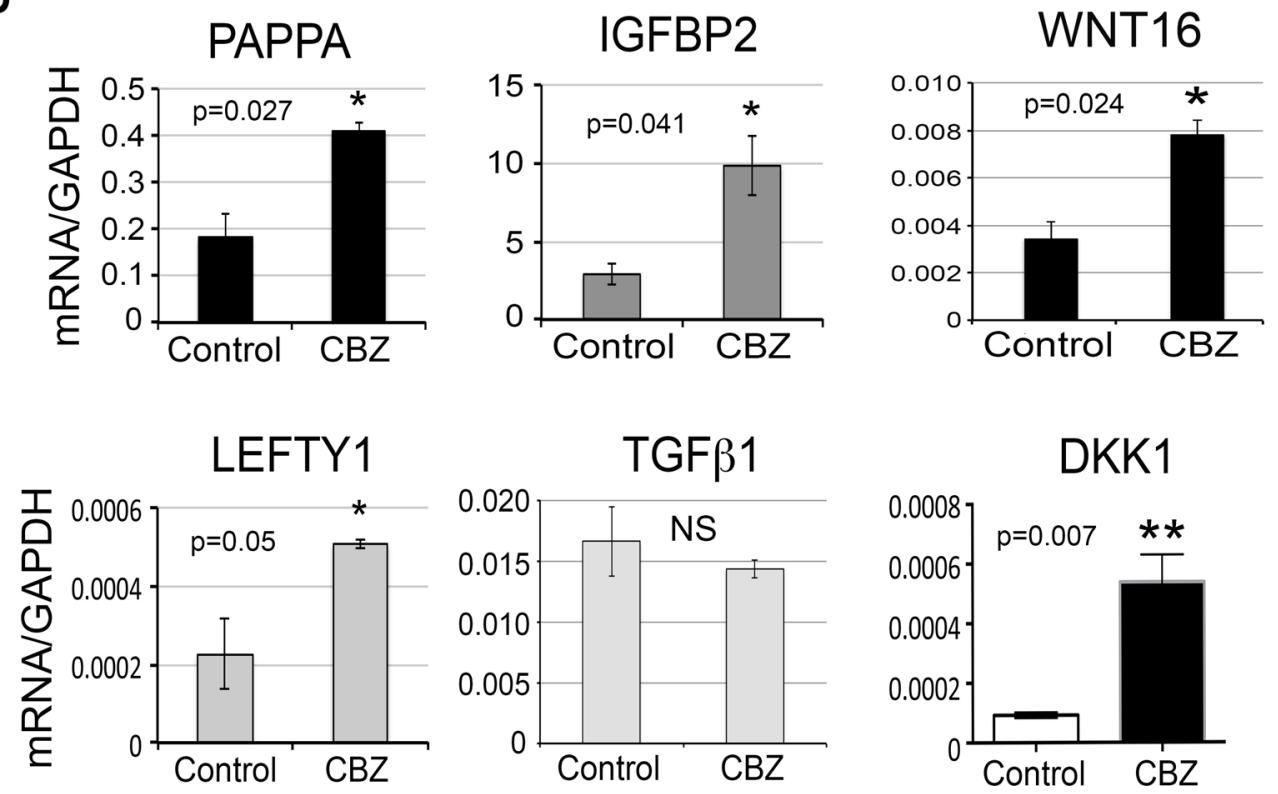

Figure 4: Secretory proteins upregulated by cabozantinib treatment. (A) Secretory proteins that may be involved in "prostate cancer" and "invasion of tumor cells" from IPA. (B) Real-time RT-PCR for the mRNA levels of several secretory proteins in the RNAs prepared from D24 osteoblasts with or without cabozantinib treatment. *, p<0.05, ${ }^{* *}, \mathrm{p}<0.01$. 
One of the clinical responses to cabozantinib treatment in men with PCa and bone metastasis is the reduction of the intensity of lesions on bone scans [3, $6,30]$. Because positivity in bone scan reflects new bone formation, these clinical outcomes suggest that

\section{A Pappalysin in PMO CM}

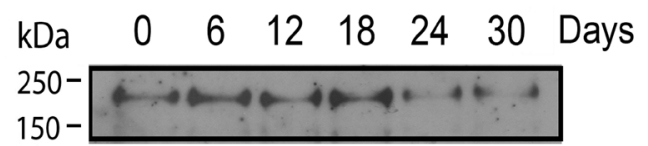

B CBZ on pappalysin

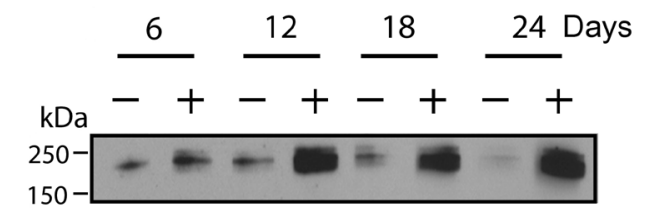

\section{IGFBP2 in PMO CM}

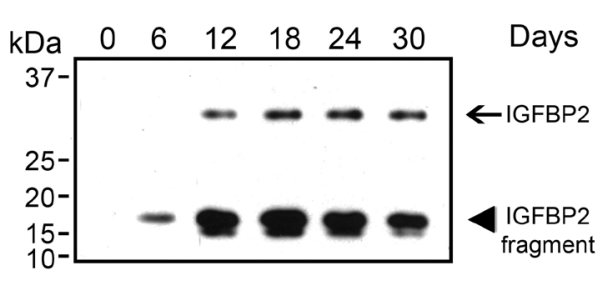

\section{CBZ on IGFBP2}

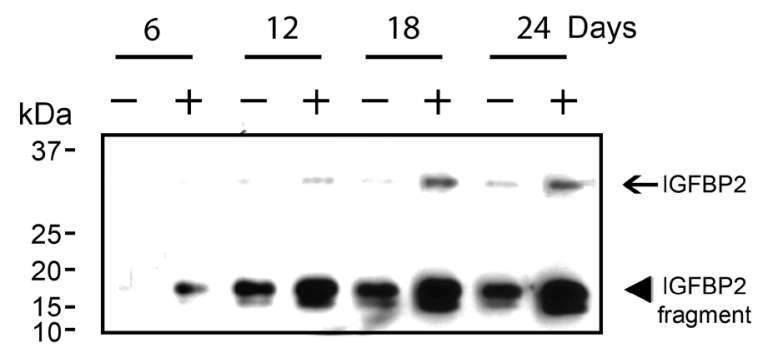

cabozantinib decreases tumor-induced bone formation. The improvement in the intensity of lesions in bone scan from cabozantinib treatment is likely due to drug effects on inhibiting tumor angiogenesis, which reduces tumor volume and in turn results in a decrease in tumor-
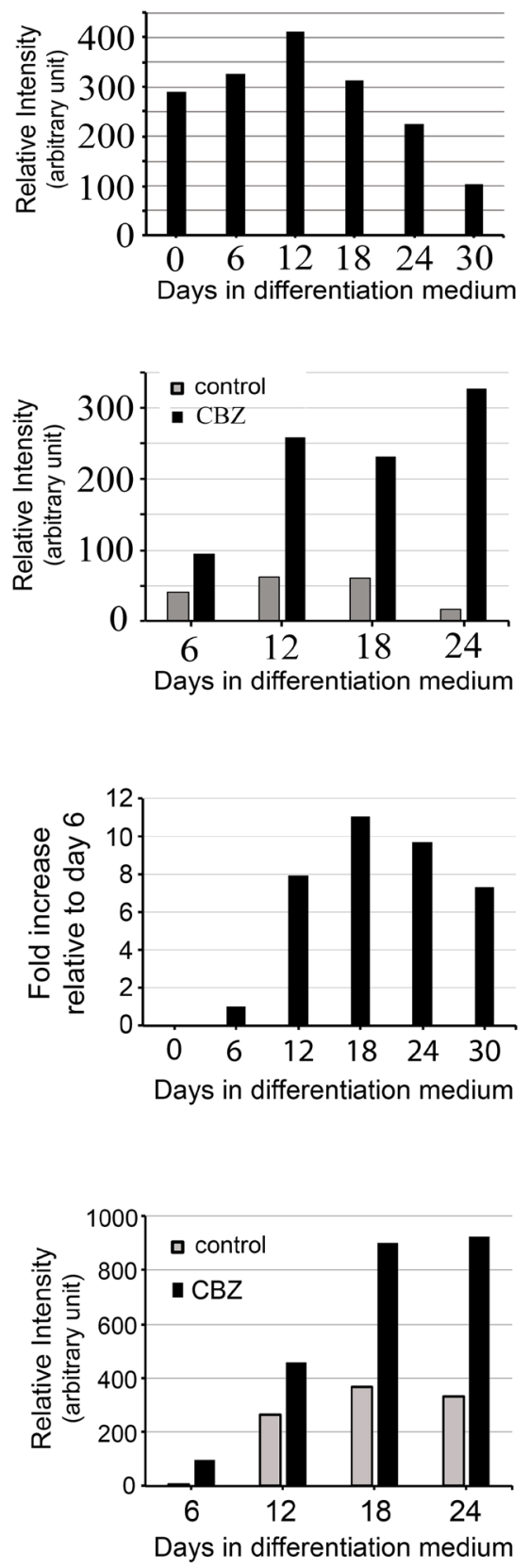

Figure 5: Effects of cabozantinib on PAPPA and IGFBP2 protein expression. (A) Left panel, Western blots for PAPPA in the conditioned medium from osteoblasts at various time points of differentiation. Right panel, quantification of the intensity of PAPPA in the Western blots. (B) Left panel, Western blots for PAPPA in the conditioned medium of osteoblasts treated with or without cabozantinib. Right panel, quantification of the intensity of PAPPA in the Western blots showed significant increase of PAPPA by cabozantinib treatment compared to control. (C) Left panel, Western blots for the expression of IGFBP2 in the conditioned medium from osteoblasts at various time points of differentiation. IGFBP2 is a protein with an apparent molecular mass of around $30 \mathrm{kDa}$ and it could be proteolyzed to 17 and $12 \mathrm{kDa}$ fragments. Right panel, quantification of the intensity of total IGFBP2 in the Western blots showed IGFBP2 expression was increased after differentiation for 12 days and remained increased throughout the time course of differentiation. (D) Left panel, Western blots for IGFBP2 in the conditioned medium of osteoblasts treated with or without cabozantinib. Right panel, quantification of the intensity of total IGFBP2 in the Western blots showed significant increase of IGFBP2 by cabozantinib treatment compared to control. 
induced new bone formation. However, Phase III study of cabozantinib in previously treated metastatic castrationresistant PCa patients showed that cabozantinib did not have an effect on PSA outcomes [3]. Our study implies that one of the reasons for the improved bone scans is inhibition of osteoblast proliferation that leads to decreased new bone formation, providing the cause of the disconnect between bone scan improvement and clinical progression.

The cabozantinib concentration used in this in vitro study is $100 \mathrm{nM}$. It is possible that different concentrations of cabozantinib might result in differential transcriptomic changes in osteoblasts. However, the concentration of cabozantinib in patients' bone is unknown. The dose of cabozantinib used in patients is $60 \mathrm{mg}$ per day [3], which is around $1 \mathrm{mg} / \mathrm{kg}$. In animal studies by Haider et al [31], the dose used was $30 \mathrm{mg} / \mathrm{kg}$ and that in Patnaik et al. [32] was $100 \mathrm{mg} / \mathrm{kg}$. Studies by Patnaik et al. [32] measured the steady-state intratumoral concentration of cabozantinib and found it to be approximately $10 \mu \mathrm{mol} / \mathrm{L}$ within 72 hours. Although the concentration in the mouse bone may not be comparable to those in human, if we calculate the concentration in bone based on the dose of cabozantinib used in human versus mouse, i.e., $1 \mathrm{mg} / \mathrm{kg}$ versus $100 \mathrm{mg} / \mathrm{kg}$, the concentration of cabozantinib in patients' bone would be approximately $0.1 \mu \mathrm{mol} / \mathrm{L}$. Thus, the cabozantinib concentration we used may be close to the cabozantinib concentration in patients' bone.

With a significant increase in drugs available for cancer treatment, acquired resistance to anticancer treatments becomes an important issue in cancer therapy. While tumor cells have been frequently shown
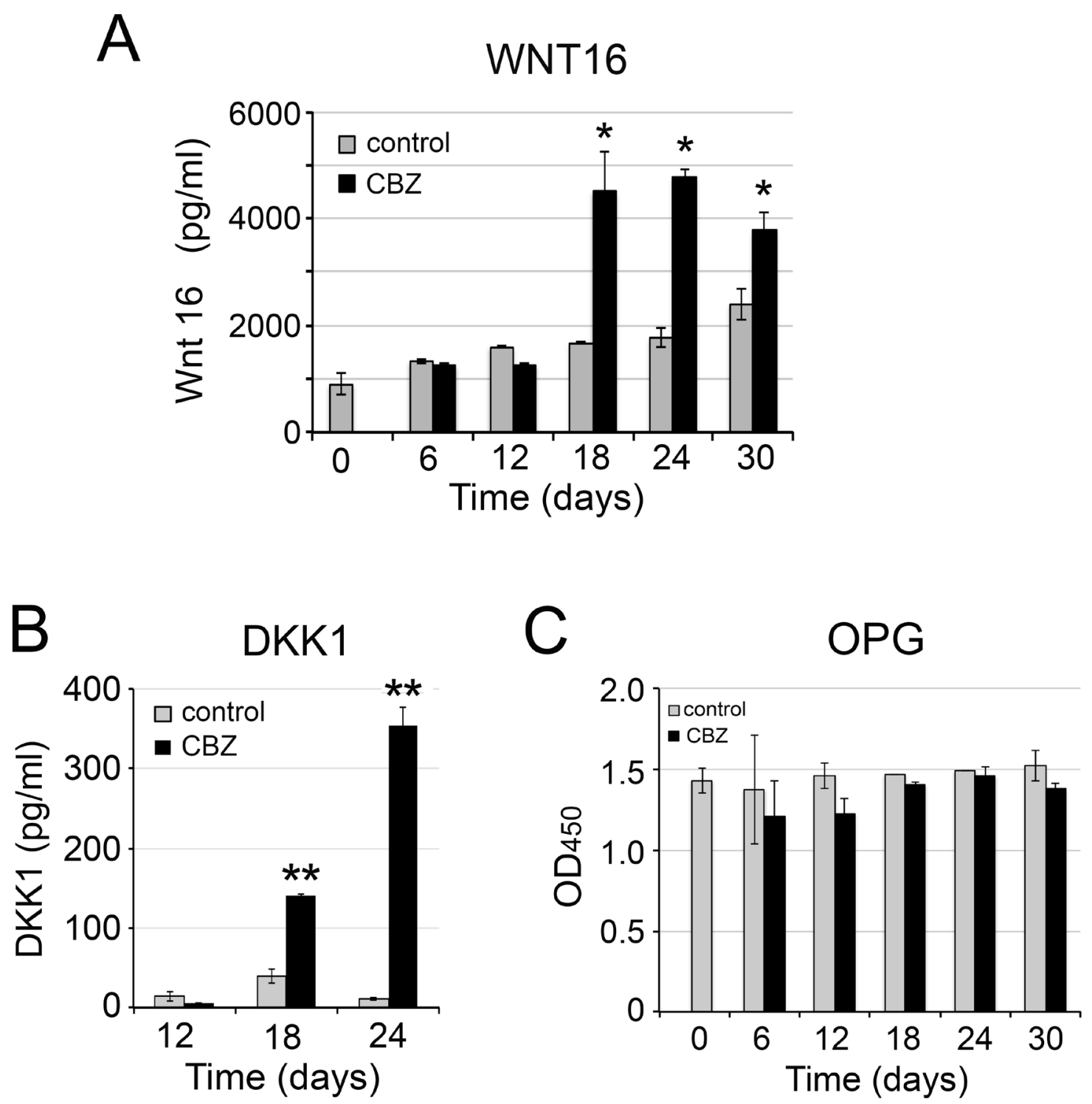

Figure 6: Effect of cabozantinib on WNT16, DKK1, and OPG expression. ELISA of (A) WNT 16, (B) DKK1, (C) OPG in the conditioned medium from osteoblasts with or without cabozantinib treatments. ${ }^{*}, p<0.05,{ }^{* *}, p<0.01$. 
to acquire therapy resistance through adaptation to anticancer treatments, treatment-induced damage to the tumor microenvironment can also contribute to therapy resistance. For example, radiation-induced WNT16 expression from tumor stroma was shown to promote tumor cell survival, resulting in attenuated effects of cytotoxic chemotherapy [15]. Interestingly, we found that cabozantinib induces a spectrum of secreted proteins, including WNT16, from osteoblasts. Resistance to cabozantinib treatments has been seen in the treatment of PCa bone metastasis [3]. Three resistance mechanisms to cabozantinib therapy have been reported so far. The first

A Anchorage-independent Growth
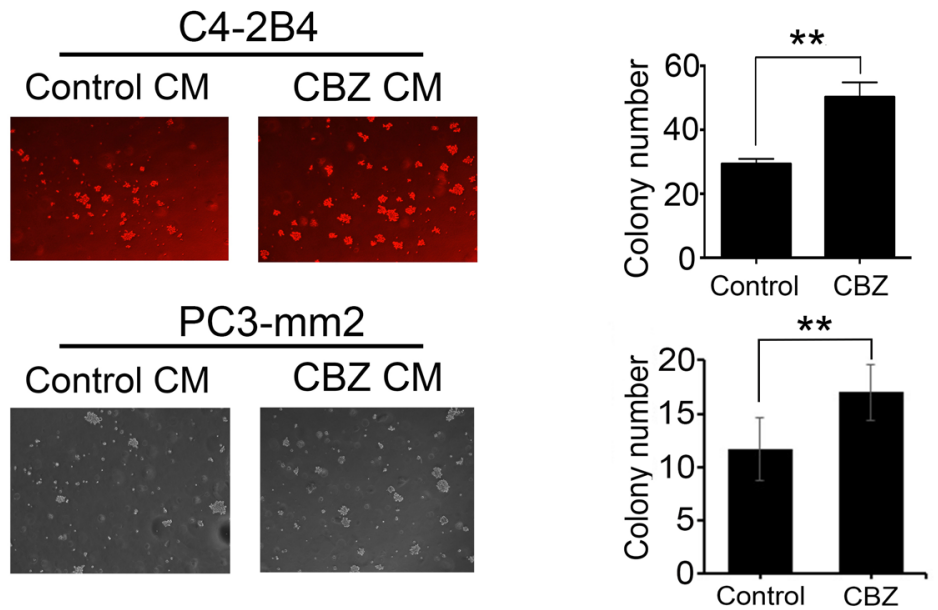

B Migration
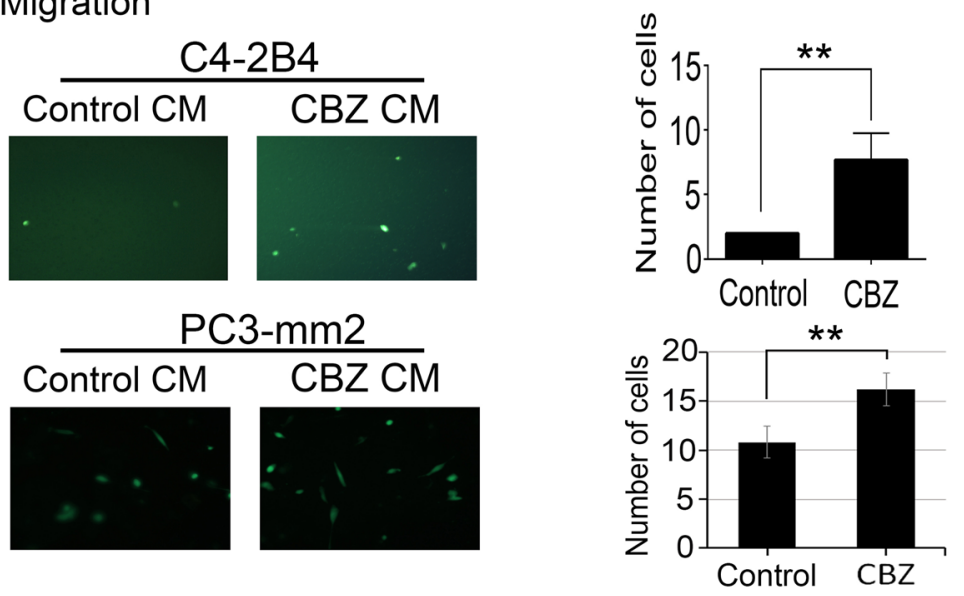

C

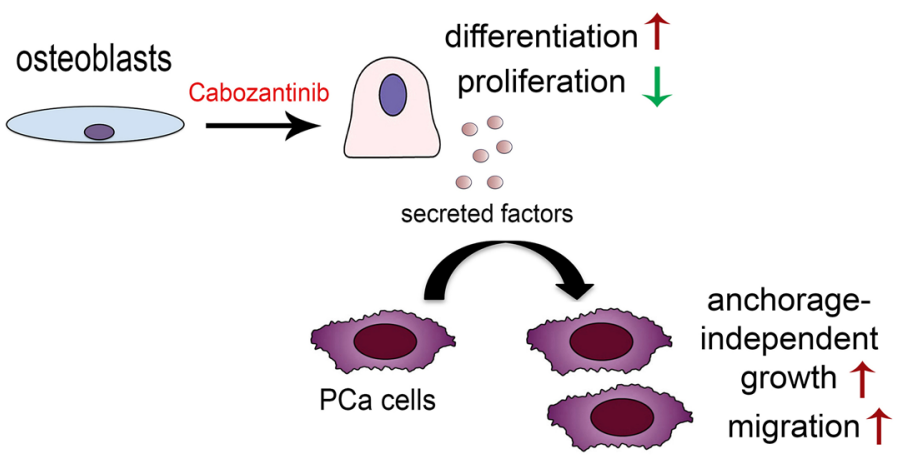

Figure 7: Effect of conditioned medium from cabozantinib-treated osteoblasts on anchorage-independent growth and migration of C4-2B4 or PC3-mm2 prostate cancer cells. (A) Soft agar colony assay showed CBZ CM significantly increase C4-2B4 colonies compared to control CM. (B) CBZ CM increased the migration of C4-2B4 cells compared to control CM in Transwell migration assay. (C) Diagram illustrates effects of cabozantinib on osteoblasts and cabozantinib-induced secreted factors may promote survival and migration of PCa cells. ${ }^{* *}, \mathrm{p}<0.01$. 
mechanism is "de novo resistance", in which the tumorinduced bone secretes factors that activate integrin and confer a survival advantage to tumor cells [7]. The second mechanism involves vascular heterogeneity. Vakaris et al. [6] showed that viable tumor cells surrounding VEGFR1positive vessels were resistant to cabozantinib treatments. The third mechanism is that targeting MET kinase leads to the activation of FGFR1 that promotes tumor proliferation and metastatic growth in bone [6]. Our studies reveal a fourth resistance mechanism, in which cabozantinib induces the secretion of a spectrum of proteins, e.g. PAPPA and IGFBP2 that are known to increase tumorigenic properties of PCa cells, from osteoblasts to increase the survival and migration of tumor cells.

In summary, our studies indicate that targeted therapy may generate diverse responses in different cell types present in tumors. Our studies raise an important issue on the impact of tumor microenvironment and therapy outcome. Some of the identified secreted factors may be suitable as biomarkers for assessing emerging therapy resistance. Understanding the effect of cabozantinib on osteoblasts may provide rationale for combination therapies that could overcome resistance.

\section{MATERIALS AND METHODS}

\section{Treatment of calvarial osteoblasts with cabozantinib}

Primary mouse osteoblasts (PMO) were isolated from calvaria of 2-5 day old newborn mice. Calvariae were digested with collagenase $(0.1 \mathrm{mg} / \mathrm{mL})$ in $\alpha$-MEM with trypsin $(12.5 \mu \mathrm{g} / \mathrm{mL})$. The first two digestions were discarded and the calvariae were further digested with 0.2 $\mathrm{mg} / \mathrm{mL}$ collagenase. The osteoblasts in the supernatants and the remaining calvariae were collected and cultured in $\alpha$-MEM plus $10 \%$ fetal bovine serum. Osteoblasts were collected from the culture by trypsin digestion. For proliferation assay, PMOs cultured in $\alpha$-MEM plus $10 \%$ fetal bovine serum (FBS) were treated with or without 100 $\mathrm{nM}$ cabozantinib (Exelixis Inc. through Material Transfer Agreement). For the differentiation assay, PMOs that were grown to confluence were cultured in differentiation medium ( $\alpha$-MEM, 10\% FBS, $100 \mu \mathrm{g} / \mathrm{ml}$ ascorbic acid, and $5 \mathrm{mM}$ $\beta$-glycerol phosphate) with or without $100 \mathrm{nM}$ cabozantinib for 30 days with a medium change every three days. The conditioned media (CMs) was collected and stored at $-20^{\circ} \mathrm{C}$ until used. PMOs were washed with phosphate buffered saline (PBS) and either scraped from the plate in $0.5 \%$ Triton X-100/PBS solution for alkaline phosphatase activity measurement or in Trizol for RNA preparation.

\section{RNA preparation and real-time RT-PCR}

Total RNAs were prepared from control untreated PMOs and cabozantinib-treated PMOs by using Trizol
(Invitrogen). RNAs were further purified by RNeasy mini kit (Qiagen, Valencia, CA, USA) and cDNAs prepared by using TagMan Reverse Transcription Reagent kit (Applied Biosystems, Foster City, CA, USA). cDNA (20 ng) was used in quantitative real-time PCR with SYBR Green (Applied Biosystems), using GAPDH as a control. For each gene of interest, three mouse-specific PCR primers were selected and verified, based on the predicted sizes of PCR products and the lack of non-specific PCR products, using cDNAs from MC3T3-E1 pre-osteoblastic cell line or from $2 \mathrm{H} 11$ endothelial cell line. The best primer set was selected for real-time RT-PCR studies. The PCR primer sequences are listed in Supplementary Table 1.

\section{Proliferation assay}

Primary mouse osteoblasts cultured in $\alpha$-MEM medium plus $10 \%$ FBS were treated with or without 100 $\mathrm{nM}$ cabozantinib. Cells were trypsinzed from the culture plate at the indicated times and the cell number counted with a hemocytometer.

\section{Measurement of alkaline phosphatase activity}

Primary mouse osteoblasts cultured in differentiation medium ( $\alpha$-MEM, 10\% FBS, $100 \mu \mathrm{g} / \mathrm{ml}$ ascorbic acid, and $5 \mathrm{mM} \beta$-glycerol phosphate) were treated with or without $100 \mathrm{nM}$ cabozantinib. Cells were lysed by using Diethanolamine Substrate Buffer (Thermo Scientific) at indicated time points. Alkaline phosphatase activity in the cell lysate was assayed by using p-nitrophenylphosphate as substrate and the absorbance measured at $405 \mathrm{~nm}$.

\section{ELISA}

Conditioned media from primary mouse osteoblasts cultured in differentiation medium with or without treating with $100 \mathrm{nM}$ cabozantinib for various duration of time were collected. The levels of specific protein in conditioned medium were measured using ELISA kits from the following source: Osteocalcin (Alfa Aesar, Tewksbury, MA, USA), WNT16 (LifeSpan BioSciences, Seattle, WA, USA), DKK1 (R\&D systems, Minneapolis, MN, USA), OPG (RayBiotech, Norcross, GA, USA), and RANKL (R\&D systems, Minneapolis, MN, USA).

\section{Mineralization assay}

For alizarin red $\mathrm{S}$ staining (Sigma, St Louis, MO, USA), primary mouse osteoblasts cultured in differentiation medium with or without treating with 100 $\mathrm{nM}$ cabozantinib for 24 days were fixed in $10 \%$ formalin for 30 minutes. After removal of $10 \%$ formalin, alizarin red $\mathrm{S}$ solution was applied at room temperature in dark for 45 minutes. For von Kossa staining, primary mouse osteoblasts cultured in differentiation medium with or without treating with $100 \mathrm{nM}$ cabozantinib for 24 days 
were fixed with cold methanol for 20 minutes, followed with the addition of 5\% silver nitrate. The culture plates were placed in a UV crosslinker with a setting at $12000 \mathrm{u}$ joules for two cycles.

\section{Gene array analysis}

Duplicate sets of RNAs prepared from PMOs treated with or without cabozantinib for 30 days were subjected to a whole-genome microarray analysis, using the Whole Mouse Genome Oligo Microarray (4x44K, Agilent Technologies) platform (Arraystar Inc., Rockville, MD, USA). Differentially expressed genes between two groups with statistical significance were identified. Array data are deposited in NCBI GEO under accession number GSE90127.

\section{Ingenuity Pathway Analysis}

Ingenuity Pathway Analysis software (IPA, Ingenuity Systems, Inc., Redwood City, CA, USA; http:// www.ingenuity.com) was used to identify pathways that are affected by cabozantinib treatment. For network and pathway connection, a dataset with gene identifiers, corresponding fold change and $\mathrm{p}$ values was uploaded into IPA with default settings to match the gene types and locations contained in the Ingenuity Knowledge Base. The threshold was set with fold change more than 2 and $\mathrm{p}$ value $<0.05$ for the IPA program to start core analyses. The canonical pathways involved in upregulated and downregulated genes were sorted based on z-scores provided by IPA program. The Search Diseases and Functions Tool was used to connect the genes encoding extracellular proteins to activities related to " $\mathrm{PCa}$ and invasion of tumor cell line".

\section{Western blot}

Conditioned media were denatured in SDS using 4x SDS sample buffer (Novex) and separated in SDS-PAGE gels (Invitrogen, NuPAGE 4-12\% Bis-Tris Gel). The proteins were transferred onto nitrocellulose membrane (Thermo Scientific), immunoblotted with antibodies, and the antibody reactivities detected by ECL (Thermo Scientific). The image intensity was quantified using Image J (NIH Image, Version: 2.0.0-rc-43/1.50e).

\section{Anchorage-independent growth assay}

C4-2B4 cell line, a LNCaP subline generated by serial passages of LNCaP cells in SCID mice [33], was kindly provided by Dr. Robert Sikes (University of Delaware). PC3-mm 2 cell line, a PC3 subline generated by serial passage of PC3 cells in vivo [34], was kindly provided by I. J. Fidler (M. D. Anderson Cancer Center). C4-2B4 and PC3-mm2 cells were grown at $37^{\circ} \mathrm{C}$ with $5 \% \mathrm{CO} 2$ in RPMI medium containing 10\% fetal bovine serum. All of the cell lines were routinely verified by short tandem repeat DNA profiling (STR) at M.D. Anderson Cancer Center Characterized Cell Line core. All of the cell lines were routinely checked for mycoplasma contamination using MycoAlert Mycoplasma Detection Kit (Lonza, LT07-218). For soft-agar colony assay, C42B4 or PC3-mm 2 cells were suspended in $0.35 \%$ agarose in RPMI-1640 medium with 5\% FBS. The cells were overlaid with top agar contained $0.7 \%$ agarose in the same medium. Conditioned medium from PMOs treated with or without cabozantinib was added to the culture medium and the medium was changed every other day. The cells were cultured for 7 days and the cell colonies in each well were counted under microscopy.

\section{Transwell migration assay}

C4-2B4 or PC3-mm2 cells were cultured to confluence in a medium containing 1:1 ratio of RPMI1640 and $\alpha$-MEM containing $10 \%$ FBS. The cells were then cultured in serum-free medium for 24 hours, trypsinized from the plates, and $0.3 \mathrm{ml}$ cell suspension (30 x $10^{4}$ cells) was loaded to Transwell chambers. The lower chamber of the migration assay in 24-well plate contained CM $(0.5 \mathrm{ml})$ from osteoblasts treated with or without cabozantinib. The transwell chamber was inserted into the wells and the cells were cultured at $37^{\circ} \mathrm{C}$. After incubation for 16 hours, the migrated cells were stained with Calcein AM (Invitrogen). Cells in the upper chamber were removed by using cotton sticks and the cells that migrated through the membrane were quantified in ten randomly chosen fields.

\section{Statistical analysis}

Statistical analyses were performed using Student's t-test (two-tailed, paired). Data are expressed as the mean \pm SD unless otherwise stated. $p$ values less than 0.05 were considered significant.

\section{Author contributions}

Conceptualization and design of study: Sue-Hwa Lin, Li-Yuan Yu-Lee, Gary E. Gallick, Mark A. Titus.

Acquisition of data: Kai-Jie Yu, Jeffrey K. Li, YuChen Lee, Guoyu Yu, Song-Chang Lin, Tianhong Pan.

Analysis and/or interpretation of data: Kai-Jie Yu, Jeffrey K. Li, Tianhong Pan, Robert L. Satcher, Sue-Hwa Lin, Li-Yuan Yu-Lee, Gary E. Gallick.

Drafting the manuscript: Sue-Hwa Lin, Kai-Jie Yu.

Revising the manuscript critically for important intellectual content: Sue-Hwa Lin, Li-Yuan Yu-Lee, Gary E. Gallick, Robert L. Satcher, Mark A. Titus.

Approval of the version of the manuscript to be published: Kai-Jie Yu, Jeffrey K. Li, Yu-Chen Lee, Guoyu $\mathrm{Yu}$, Song-Chang Lin, Tianhong Pan, Robert L. Satcher, 
Mark A. Titus, Li-Yuan Yu-Lee, Wen Hui Weng, Gary E. Gallick, Sue-Hwa Lin.

\section{CONFLICTS OF INTEREST}

No conflicts of interest was reported by all authors in this study.

\section{FUNDING}

This work was supported by grants from the NIH including CA174798, 5P50 CA140388 and CA16672, the Prostate Cancer Foundation, Cancer Prevention and Research Institute of Texas (CPRIT RP110327, CPRIT RP150179, CPRIT RP150282), funds from the University Cancer Foundation via the Sister Institute Network Fund at the MD Anderson Cancer Center.

\section{REFERENCES}

1. Yakes FM, Chen J, Tan J, Yamaguchi K, Shi Y, Yu P, Qian F, Chu F, Bentzien F, Cancilla B, Orf J, You A, Laird AD, et al. Cabozantinib (XL184), a novel MET and VEGFR2 inhibitor, simultaneously suppresses metastasis, angiogenesis, and tumor growth. Mol CancerTher. 2011; 10:2298-2308.

2. Leibowitz-Amit R, Pintilie M, Khoja L, Azad AA, Berger $\mathrm{R}$, Laird AD, Aftab DT, Chi KN, Joshua AM. Changes in plasma biomarkers following treatment with cabozantinib in metastatic castration-resistant prostate cancer: a post hoc analysis of an extension cohort of a phase II trial. J Transl Med. 2016; 14:12.

3. Smith M, De Bono J, Sternberg C, Le Moulec S, Oudard S, De Giorgi U, Krainer M, Bergman A, Hoelzer W, De Wit R, Bogemann M, Saad F, Cruciani G, et al. Phase III Study of Cabozantinib in Previously Treated Metastatic CastrationResistant Prostate Cancer: COMET-1. J Clin Oncol. 2016; 34:3005-3013.

4. Logothetis C, Lin SH. Osteoblasts in prostate cancer metastasis to bone. Nat Rev Cancer. 2005; 5:21-28.

5. Singh H, Brave M, Beaver JA, Cheng J, Tang S, Zahalka E, Palmby TR, Venugopal R, Song P, Liu Q, Liu C, Yu J, Chen XH, et al. U.S. Food and Drug Administration Approval: Cabozantinib for the Treatment of Advanced Renal Cell Carcinoma. Clin Cancer Res. 2017; 23:330-335.

6. Varkaris A, Corn PG, Parikh NU, Efstathiou E, Song JH, Lee YC, Aparicio A, Hoang AG, Gaur S, Thorpe L, Maity SN, Bar Eli M, Czerniak BA, et al. Integrating Murine and Clinical Trials with Cabozantinib to Understand Roles of MET and VEGFR2 as Targets for Growth Inhibition of Prostate Cancer. Clin Cancer Res. 2016; 22:107-121.

7. Lee YC, Lin SC, Yu G, Cheng CJ, Liu B, Liu HC, Hawke DH, Parikh NU, Varkaris A, Corn P, Logothetis C, Satcher RL, Yu-Lee LY, et al. Identification of Bone-Derived Factors
Conferring De Novo Therapeutic Resistance in Metastatic Prostate Cancer. Cancer Res. 2015; 75:4949-4959.

8. Dai J, Zhang H, Karatsinides A, Keller JM, Kozloff KM, Aftab DT, Schimmoller F, Keller ET. Cabozantinib inhibits prostate cancer growth and prevents tumor-induced bone lesions. Clin Cancer Res. 2014; 20:617-630.

9. Nguyen HM, Ruppender N, Zhang X, Brown LG, Gross TS, Morrissey C, Gulati R, Vessella RL, Schimmoller F, Aftab DT, Corey E. Cabozantinib inhibits growth of androgensensitive and castration-resistant prostate cancer and affects bone remodeling. PLoS One. 2013; 8:e78881.

10. Deckers MM, Karperien M, van der Bent C, Yamashita T, Papapoulos SE, Lowik CW. Expression of vascular endothelial growth factors and their receptors during osteoblast differentiation. Endocrinology. 2000; 141:1667-1674.

11. Mauro LJ, Olmsted EA, Skrobacz BM, Mourey RJ, Davis AR, Dixon JE. Identification of a hormonally regulated protein tyrosine phosphatase associated with bone and testicular differentiation. J Biol Chem. 1994; 269:30659-30667.

12. Chengalvala MV, Bapat AR, Hurlburt WW, Kostek B, Gonder DS, Mastroeni RA, Frail DE. Biochemical characterization of osteo-testicular protein tyrosine phosphatase and its functional significance in rat primary osteoblasts. Biochemistry. 2001; 40:814-821.

13. James AW, Shen J, Zhang X, Asatrian G, Goyal R, Kwak JH, Jiang L, Bengs B, Culiat CT, Turner AS, Seim Iii $\mathrm{HB}$, Wu BM, Lyons K, et al. NELL-1 in the treatment of osteoporotic bone loss. Nat Commun. 2015; 6:7362.

14. Abdallah BM, Ditzel N, Mahmood A, Isa A, Traustadottir GA, Schilling AF, Ruiz-Hidalgo MJ, Laborda J, Amling M, Kassem M. DLK1 is a novel regulator of bone mass that mediates estrogen deficiency-induced bone loss in mice. $\mathrm{J}$ Bone Miner Res. 2011; 26:1457-1471.

15. Sun Y, Campisi J, Higano C, Beer TM, Porter P, Coleman I, True L, Nelson PS. Treatment-induced damage to the tumor microenvironment promotes prostate cancer therapy resistance through WNT16B. Nat Med. 2012; 18:1359-1368.

16. Meno C, Saijoh Y, Fujii H, Ikeda M, Yokoyama T, Yokoyama M, Toyoda Y, Hamada H. Left-right asymmetric expression of the TGF beta-family member lefty in mouse embryos. Nature. 1996; 381:151-155.

17. Meno C, Shimono A, Saijoh Y, Yashiro K, Mochida K, Ohishi S, Noji S, Kondoh H, Hamada H. lefty-1 is required for left-right determination as a regulator of lefty-2 and nodal. Cell. 1998; 94:287-297.

18. Gerard N, Delpuech T, Oxvig C, Overgaard MT, Monget P. Proteolytic degradation of IGF-binding protein (IGFBP)-2 in equine ovarian follicles: involvement of pregnancyassociated plasma protein-A (PAPP-A) and association with dominant but not subordinated follicles. J Endocrinol. 2004; 182:457-466. 
19. Fioramonti M, Santini D, Iuliani M, Ribelli G, Manca P, Papapietro N, Spiezia F, Vincenzi B, Denaro V, Russo A, Tonini G, Pantano F. Cabozantinib targets bone microenvironment modulating human osteoclast and osteoblast functions. Oncotarget. 2017; 8:20113-20121. https://doi.org/10.18632/oncotarget.15390.

20. Stern PH, Alvares K. Antitumor agent cabozantinib decreases RANKL expression in osteoblastic cells and inhibits osteoclastogenesis and PTHrP-stimulated bone resorption. J Cell Biochem. 2014; 115:2033-2038.

21. Engelmann JC, Amann T, Ott-Rotzer B, Nutzel M, Reinders Y, Reinders J, Thasler WE, Kristl T, Teufel A, Huber CG, Oefner PJ, Spang R, Hellerbrand C. Causal Modeling of Cancer-Stromal Communication Identifies PAPPA as a Novel Stroma-Secreted Factor Activating NFkappaB Signaling in Hepatocellular Carcinoma. PLoS Comput Biol. 2015; $11: \mathrm{e} 1004293$.

22. Moore MG, Wetterau LA, Francis MJ, Peehl DM, Cohen P. Novel stimulatory role for insulin-like growth factor binding protein-2 in prostate cancer cells. Int J Cancer. 2003; 105:14-19.

23. Kiyama S, Morrison K, Zellweger T, Akbari M, Cox M, Yu D, Miyake H, Gleave ME. Castration-induced increases in insulin-like growth factor-binding protein 2 promotes proliferation of androgen-independent human prostate LNCaP tumors. Cancer Res. 2003; 63:3575-3584.

24. Inman BA, Harel F, Audet JF, Meyer F, Douville P, Fradet $\mathrm{Y}$, Lacombe L. Insulin-like growth factor binding protein 2: an androgen-dependent predictor of prostate cancer survival. Eur Urol. 2005; 47:695-702.

25. Cohen P, Peehl DM, Stamey TA, Wilson KF, Clemmons DR, Rosenfeld RG. Elevated levels of insulin-like growth factor-binding protein-2 in the serum of prostate cancer patients. J Clin Endocrinol Metab. 1993; 76:1031-1035.

26. Kanety H, Madjar Y, Dagan Y, Levi J, Papa MZ, Pariente C, Goldwasser B, Karasik A. Serum insulin-like growth factorbinding protein-2 (IGFBP-2) is increased and IGFBP-3 is decreased in patients with prostate cancer: correlation with serum prostate-specific antigen. J Clin Endocrinol Metab. 1993; 77:229-233.

27. Grano M, Galimi F, Zambonin G, Colucci S, Cottone E, Zallone AZ, Comoglio PM. Hepatocyte growth factor is a coupling factor for osteoclasts and osteoblasts in vitro. Proc Natl Acad Sci U S A. 1996; 93:7644-7648.

28. Lee YC, Huang CF, Murshed M, Chu K, Araujo JC, Ye X, deCrombrugghe B, Yu-Lee LY, Gallick GE, Lin $\mathrm{SH}$. Src family kinase/abl inhibitor dasatinib suppresses proliferation and enhances differentiation of osteoblasts. Oncogene. 2010 29:3196-3207.

29. O'Sullivan S, Naot D, Callon KE, Watson M, Gamble GD, Ladefoged M, Karsdal MA, Browett P, Cornish J, Grey A. Imatinib mesylate does not increase bone volume in vivo. Calcif Tissue Int. 2011; 88:16-22.

30. Smith MR, Sweeney CJ, Corn PG, Rathkopf DE, Smith DC, Hussain M, George DJ, Higano CS, Harzstark AL, Sartor AO, Vogelzang NJ, Gordon MS, de Bono JS, et al. Cabozantinib in Chemotherapy-Pretreated Metastatic Castration-Resistant Prostate Cancer: Results of a Phase II Nonrandomized Expansion Study. J Clin Oncol. 2014; 32:3391-3399.

31. Haider MT, Hunter KD, Robinson SP, Graham TJ, Corey E, Dear TN, Hughes R, Brown NJ, Holen I. Rapid modification of the bone microenvironment following short-term treatment with Cabozantinib in vivo. Bone. 2015; 81:581-592.

32. Patnaik A, Swanson KD, Csizmadia E, Solanki A, LandonBrace N, Gehring MP, Helenius K, Olson BM, Pyzer AR, Wang LC, Elemento O, Novak J, Thornley TB, et al. Cabozantinib Eradicates Advanced Murine Prostate Cancer by Activating Antitumor Innate Immunity. Cancer Dis. 2017.

33. Wu TT, Sikes RA, Cui Q, Thalmann GN, Kao C, Murphy CF, Yang H, Zhau HE, Balian G, Chung LW. Establishing human prostate cancer cell xenografts in bone: induction of osteoblastic reaction by prostate-specific antigen-producing tumors in athymic and SCID/bg mice using $\mathrm{LNCaP}$ and lineage-derived metastatic sublines. Int J Cancer. 1998; 77:887-894.

34. Delworth M, Nishioka K, Pettaway C, Gutman M, Killion J, Voneschenbach A, Fidler I. Systemic administration of 4-amidinoindanon-1-(2'-amidino)-hydrazone, a new inhibitor of s-adenosylmethionine decarboxylase, produces cytostasis of human prostate-cancer in athymic nude-mice. Int J Oncol. 1995; 6:293-299. 